\title{
The development of energy conservation policy of buildings in China: a comprehensive review and analysis
}

Article

Accepted Version

Han, S., Yao, R. and Li, N. (2021) The development of energy conservation policy of buildings in China: a comprehensive review and analysis. Journal of Building Engineering, 38. 102229. ISSN 2352-7102 doi:

https://doi.org/10.1016/j.jobe.2021.102229 Available at https://centaur.reading.ac.uk/98277/

It is advisable to refer to the publisher's version if you intend to cite from the work. See Guidance on citing.

To link to this article DOI: http://dx.doi.org/10.1016/j.jobe.2021.102229

Publisher: Elsevier

All outputs in CentAUR are protected by Intellectual Property Rights law, including copyright law. Copyright and IPR is retained by the creators or other copyright holders. Terms and conditions for use of this material are defined in the End User Agreement.

www.reading.ac.uk/centaur 
Central Archive at the University of Reading

Reading's research outputs online 


\title{
The development of energy conservation policy of buildings in China: A Comprehensive Review and Analysis
}

\author{
Shiyu Han ${ }^{a^{*}}$, Runming Yao ${ }^{a, b}$, Nan Lib* \\ a, University of Reading, School of the Built Environment, Reading, the United Kingdom \\ ${ }^{b}$ Chongqing University, School of Civil Engineering, Chongqing, China
}

\begin{abstract}
Energy conservation policies of buildings (ECPB) comprise combined governmental forces of national plans, laws and mandatory regulations of buildings, which have proved important contribution in improving energy efficiency and reduce carbon emissions. However, increasing the effectiveness of national policy is a challengeable task due to the complexities of historical, social, economic and environmental problems involved. Future policy designs of ECPB should be very careful and scientific from retrospect of their appeared achievements and problems from policies implemented in history. It is therefore important to fully understand the development of the ECPB, of particular note is the way the policy system has been progressively developed over time, which have not been formally and comprehensively studied yet. In this research, a chronological review method is first developed to review, retrospect and analyse the historical development, policy content, and policy effectiveness of China's building energy conservation. The aim of this review paper is to provide comprehensive information and analytical insights for both policymakers and scholars of building energy conservation researches. From this review research, the milestone policy and achievements of ECPB historical development are evaluated, and their policy barriers and possible improvements are discovered. Accordingly, this method can provide important knowledge to support and improve future policy design and policy system development in building energy conservation.
\end{abstract}

\section{Keywords}

Energy Policy, Energy Conservation, Building Energy Efficiency, Historical Development

\author{
Abbreviation \\ ECPB -- Energy Conservation Policies of Buildings \\ GPEBE - Governmental Policies of Energy, Building and Environment \\ BEES - Building Energy Efficiency Standards \\ FYP - the Five-Year Plan \\ HVAC - Heating, Ventilation and Air-Conditioning \\ SC \& C - Server Cold and Cold \\ HSCW - Hot Summer and Cold Winter \\ HSWW - Hot Summer and Warm Winter \\ CGBL - China Green Building Label
}


EPC - Energy Performance Contracting

TGPUG - Technical Guidelines of Passive, Ultra-low energy consumption, and Green buildings

TSNZE - Technical Standard for Nearly-Zero Energy building (as GB/T 51350-2019)

RED - Renewable Energy Directive

$\mathrm{RO}$ - Renewables Obligation 


\section{Introduction}

China has undergone extensive economic development over the last four decades but is increasingly hitherto facing serious issues of energy scarcity. The country is also facing huge challenges in respect of environmental quality due to heavy pollutions resulting from rapid industrialisation and ongoing processes of urbanisation. The broader impact on climate change is a global concern.

Among many aspects of sustainable development, energy and carbon emission are perhaps the most essential themes. In particular, building energy efficiency is the declared primary mission of China's energy and carbon reduction programme [1]. Statistics show that the building sector currently accounts for approximately $27.5 \%$ of total national energy consumption, and is likely to increase to $30 \%$ in the future [2]. Moreover, from 1978 to 2012, the rate of urbanization in China has increased from $17.9 \%$ to $52.6 \%$ [3], and it continues to increase at a seemingly exponential rate. With a huge large population base and everincreasing growth, China's urbanisation process places ever increasing demands of buildings. Research [4] reveals that there is an increasing demand in energy consumption for heating, cooling, ventilation and lighting to improve indoor environmental quality.

Government policy seeks to establish a coherent set of principles for the purposes of guiding decision making, and achieving rational outcomes [5]. In the energy sector, the energy conservation policies of buildings (ECPB) comprise a combination of national plans, laws and mandatory regulations for energy conservation [6]. They are widely accepted as having been effective in improving national energy efficiency and reduce carbon emissions [7-9]. Policy in the context of rapidly increasing energy consumption China has consistently sought to implement a top-down administrative energy conservation measure over the last four decades. This mechanism has been continuously developed for years and achieved significant reduction goals in energy consumption and pollution emission. The Chinese government has set up the $65 \%$ reduction target of total carbon emission based on the protocol negotiated in the 2016 Paris Agreement [10]. In the history of national development, China's energy conservation policy mechanism has significantly played an important role [11].

Yet the current situation of energy efficiency in building sector is not optimistic due to its rapidly increased urbanisation rate, population, and people's demand of improving indoor environmental quality. Especially, in China's Hot Summer and Cold Winter climate zone and rural area, the majority of people still live under very poor conditions of indoor thermal environment [12]. With their increasing economic income and demand of better living quality, the energy consumption potential for China's future could be enormous. Reflecting back to current governmental energy policies and building energy standards, there are still plenty of improvements needed to achieve for the objectives set ambitiously in energy and carbon emission reduction [2]. The question remains regards the effectiveness of future energy conservation policy of buildings. Therefore, there is a need to gain new insights through reviewing and analysing the comprehensive and detailed information of the previous implemented ECPB, while the situation is serious, and the majority of current policy review studies are not comprehensive enough and cover the long timeline in whole country scale. 


\section{Literature review of previous ECPB studies}

This paper aims at the development of an approach to conduct an integrated review of energy conservation policies of buildings and their effectiveness, and to provide valuable information and analytical insights for both policymakers and scholars of building energy conservation. Therefore, the literature review of previous ECPB studies is required to find the research gap and policy barriers in the field.

\subsection{Lack of coherent analysis of ECPB development history}

To review such massive amount of literature during 40 years, the archival study is an effective method [5, 13] and has been widely used in a comprehensive informative review studies for policy [14, 15]. It is proven that important insights can be gleaning by considered how the ECPB were being developed over time [16, 17]. As the limitation of previous literature of ECPB archival study papers, relatively few archival ECPB researches adopted a chronological review of the historical events which drove ECPB development. For example, Li and Shui [18] inferred some limitations of current building energy conservation standards; Hong [19], Yan et al. [20] reviewed the building ECPB content and compared with policies issued in other developed countries. However, their statements might be too general without enough support from comprehensive content and data analysis.

Similarly, Yang et al., Li et al. and Zhang et al. [21-23] reviewed many green building assessment codes in different countries and compared their sustainability content with limitations without involving enough country background, social and economic aspects. Likewise, three law-based studies Peng and Liu [24], Jiao and Boons [25], Zhao et al. [26] respectively analysed three single energy laws of their clause development and implementation effectiveness, but these studies did not consider much of the situation and strategy of country development, either not enough thinking of national ECPB that could affect the formulation of policies.

In general, there remains an absence of causal relationship between national development of economic, energy and environment, also without any holistic reviews of the long-term historical development of ECPB in China. Compared with relevant historical studies of ECPB packages as Economidou et al. [27] mentioned for European countries, for the last four decades, the ECPBs issued in China are chaotic without appropriate ordering due to their complex revisions and update editions. Based on the research objectives, this study should order the ECPB issued chronologically. Besides, as the governmental policies issued are usually affected by external reasons, the important historical events which related with energy policies should been also collected and arranged with the timeline.

\subsection{ECPB classification: GPEBE and BEES}

Rather than traditional policy review studies that focus on only one type of ECPB, this research requires massive amount of policy content to be reviewed, which cover all the policy types in the country. Therefore. considering the complexity and characteristics of implemented policies over the last four decades, ECPBs can be classified into two categories, as one is the general policies issued by the central government as Governmental Policies of Energy, Building and Environment (GPEBE). These policies were issued 
by the central government unit as the State Council, which provide very general guidance of national energy development strategy for a period of time. For the building sector, the ECPB for buildings has been developed into a more specific and independent system during the GPEBE development called national Building Energy Efficiency Standards (BEES). In China, these policies are core policy for energy conservation of buildings. Issued by the Ministry of Housing and Urban-Rural Development, they have much more detailed and clear engineering approaches and technical practices [28]. While GPEBE are still presenting directions and objectives for national energy conservation, building designers and policymakers in building energy aspect of China now heavily rely on these standards for their designs and studies in building energy consumption. Respectively, both GPEBE and BEES are ordered, classified, reviewed and discussed in a chronological timeline in this study.

GPEBE are policies usually issued by the national administrative and legislature offices. They routinely contain massive amounts of information about every aspect of China's development. In this paper, majority important GPEBE published by the Chinese government are reviewed and analysed. In the energy, building and environment sectors, the most important governmental agencies and their functional roles of policymaking are summarized and listed below in Table 1.

Table 1

Main governmental units of building energy policy system in China

\begin{tabular}{|c|c|c|c|}
\hline Full name & Abbreviation & Role in the policy system & Feature \\
\hline The State Council & GOV & $\begin{array}{l}\text { Central administrative unit. Provides overall } \\
\text { objectives and general directions }\end{array}$ & General \\
\hline $\begin{array}{l}\text { The National People's Congress and its } \\
\text { Standing Committee }\end{array}$ & NPC & $\begin{array}{l}\text { Central legislature unit. Decision-making of } \\
\text { general national policies and plans of laws }\end{array}$ & General \\
\hline $\begin{array}{l}\text { National Development and Reform } \\
\text { Commission }\end{array}$ & NDRC & $\begin{array}{l}\text { Provides the grand designs of national plans and } \\
\text { detailed objectives }\end{array}$ & General \\
\hline National Bureau of Statistics & NBS & $\begin{array}{l}\text { Provides national statistics for general } \\
\text { policymaking and evaluation }\end{array}$ & Detailed \\
\hline Ministry of Science and Technology & MOST & $\begin{array}{l}\text { Provides plans and related appropriation funds } \\
\text { (Ministry of Finance) for research institutions and } \\
\text { universities }\end{array}$ & Detailed \\
\hline $\begin{array}{l}\text { Ministry of Housing and Urban-Rural } \\
\text { Development (as Ministry of Construction } \\
\text { before 2008) }\end{array}$ & MOHURD & $\begin{array}{l}\text { Main governmental office of building energy } \\
\text { policies. Provides very specific and detailed } \\
\text { guidelines and plans for further social actions and } \\
\text { studies to acquire the objectives (as BEES) }\end{array}$ & Detailed \\
\hline Ministry of Ecology and Environment & MOEE & $\begin{array}{l}\text { Provides environmental situation data and plans of } \\
\text { pollution-reduction objectives }\end{array}$ & Detailed \\
\hline
\end{tabular}

In general, policymaking commences with very general policy directions and guidelines (known as the Five-Year Plans). These lay out the basic objectives required to be met within specified target times. It is then the responsibility of individual ministries to arrange the detail objectives and plans such as local policies and sectoral standards.

For BEES issued by MOHURD, however, they are energy policies specific for the building sector, as national building energy policies, including architectural standards, building performance requirement, installing parameters, and codes of thermal and HVAC designs. They provide the rules of the calculation, and some of their index could indirectly and effectively affect the energy consumption in buildings. In this paper, major civil building standards of energy efficiency design and management during the modern development should been arranged and reviewed, classified as general-purpose standards, public building standards, residential building standards, and advanced building energy standards. 
For effectively review major BEES, they can be classified into two types: first one is mandatory standards which are very comprehensive in building architecture, construction and system designs. This kind of BEES have design rules of construction, thermal design and engineering design of heating, ventilation, and air conditioning in buildings, and majority of their rules are mandatory for the construction process. Mandatory BEES can be further classified into more detailed types based on their target building types to public building standard and residential building standards. Secondly, in recent years, an even newer type of BEES has been issued. They do not have mandatory design rules, but massive new sustainable technologies, suggestions and encourage measures are introduced to building designers, with new concept such as green buildings. This is how the "advanced standards" is defined with diverse features of building engineering and technology.

\section{Methodology}

In this study, informative archival study is used for the collection of all the important national energy conservation policies implemented in building, energy and environment aspects during the China's modern development dated from 1980 to 2019. Because of a large amount of data that required review, they are listed and reviewed in accordance with specific criteria. their purposes, policy innovation points, implemented years, and positions of the policy system, with discussion of their policy content. Secondly, the literature review was conducted on governmental database and research papers which were retrieved from governmental documents, yearbooks, websites, "Science Direct" and "Google Scholar", with only peer-reviewed journal papers considered for the evaluation. The keywords used to initially filter the papers were "China", "Energy", "Policy", "Building”, then "Renewable Energy", "Sustainability”, "Low Carbon" and "Building Environmental Quality" were used to refine the research further. A set of 35 representative papers were identified, and their contents reviewed for the purposes of evaluating of the effectiveness of ECPB in China.

Furthermore, GPEBE and BEES including FYPs, national notices and actions, laws, and building energy efficient standards published in the last 40 years have been reviewed and discussed using content analysis method [29]. The next step of chronological review of policy content may explain how China has correspondingly presented their actions and solutions with milestone ECPB or international problems, such as protocols of climate change. Also, the introspection of these experience could be valuable for problem detections and future ECPB making when they are jointly analysed with historical events and follow-up effects.

Moreover, to support the discussion section, the selected academic research papers relating to ECPB development are also critically reviewed. The effectiveness of energy policy could not be accomplished by analysing governmental legislation alone. Considering the more realistic effectiveness of ECPB and massive policy content during the 50 years history, only statistics and policy content may not be reasonable proofs as they could be subject to bias. Therefore, it is also necessary to evaluate the underpinning research base upon which ECPB are based, so a series of research papers relating to China's energy policy are critically reviewed and discussed to support the discussion. Accordingly, the research method can be summarised as below in Figure 1. 


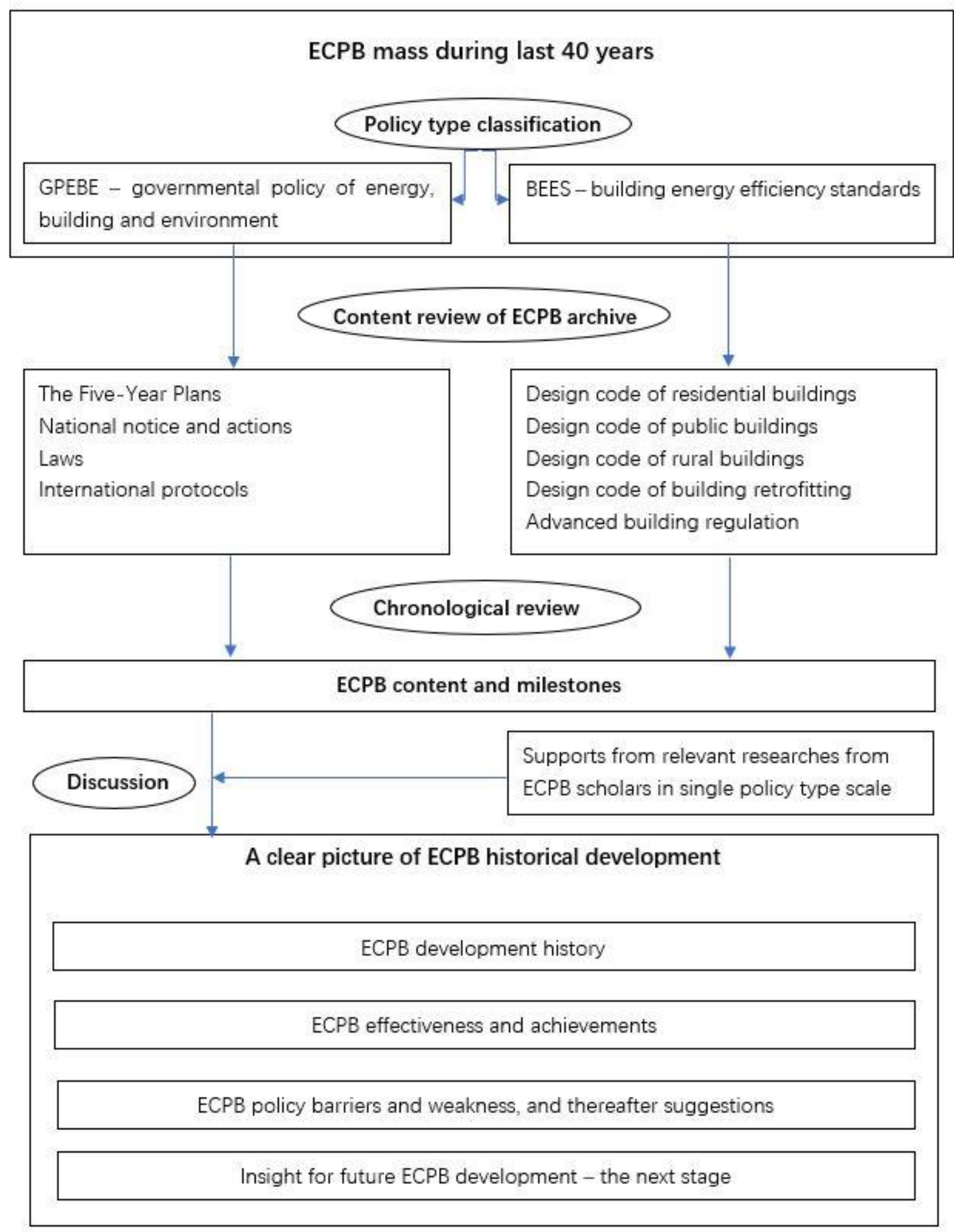

Figure 1 ECPB review research method of this study

The selected studies of GPEBE are initially classified based on the applied research methods, which are 
listed in Table 2.

Table 2

Review of policy studies with different research methods

\begin{tabular}{|c|c|c|c|c|c|}
\hline \multirow[t]{2}{*}{ Evaluation Method } & \multirow[t]{2}{*}{ Policy studied } & \multicolumn{3}{|c|}{ Focused aspects } & \multirow[t]{2}{*}{ Reference } \\
\hline & & Energy & Building & Environment & \\
\hline Statistical Analysis & Cleaner production & $\sqrt{ }$ & $\sqrt{ }$ & $\sqrt{ }$ & [24] \\
\hline Statistical Analysis & NBS energy statistics & $\sqrt{ }$ & $\sqrt{ }$ & & [30] \\
\hline Statistical Review \& Analysis & $\begin{array}{l}\text { Energy performance contracting } \\
\text { (EPC) }\end{array}$ & $\sqrt{ }$ & $\sqrt{ }$ & & [31] \\
\hline Statistical Review & Renewable energy & $\sqrt{ }$ & $\sqrt{ }$ & $\sqrt{ }$ & [32] \\
\hline Statistical \& Policy Review & Circular economy policy & $\sqrt{ }$ & & $\sqrt{ }$ & [25] \\
\hline Statistical \& Policy Review & Renewable energy & $\sqrt{ }$ & $\sqrt{ }$ & $\sqrt{ }$ & [33] \\
\hline Policy Review & $\begin{array}{l}10^{\text {th }} \text { Five-Year Plan } \\
\text { Energy laws } \\
\text { Building standards }\end{array}$ & $\sqrt{ }$ & $\sqrt{ }$ & $\sqrt{ }$ & [34] \\
\hline Policy Review & $11^{\text {th }}$ Five-Year Plan & $\sqrt{ }$ & $\sqrt{ }$ & & [35] \\
\hline Policy Review & Renewable energy & $\sqrt{ }$ & $\sqrt{ }$ & $\sqrt{ }$ & {$[36]$} \\
\hline Policy Review & $\begin{array}{l}11^{\text {th }} \text { Five-Year Plan } \\
\text { National notice }\end{array}$ & $\sqrt{ }$ & $\sqrt{ }$ & & {$[37]$} \\
\hline Policy Review & Energy Efficient Buildings & $\sqrt{ }$ & $\sqrt{ }$ & & [38] \\
\hline Policy Review & $1^{\text {st }}-12^{\text {th }}$ Five-Year Plans & $\sqrt{ }$ & $\sqrt{ }$ & $\sqrt{ }$ & [39] \\
\hline Policy Review & $\begin{array}{l}12^{\text {th }} \text { Five-Year Plan } \\
\text { National notice } \\
\text { Energy laws } \\
\text { Building standards }\end{array}$ & $\sqrt{ }$ & $\sqrt{ }$ & & {$[40]$} \\
\hline Policy Review \& Comparison & $\begin{array}{l}\text { National notice } \\
\text { Energy laws } \\
\text { Building standards }\end{array}$ & $\sqrt{ }$ & $\sqrt{ }$ & $\sqrt{ }$ & [41] \\
\hline Policy Review \& Comparison & $\begin{array}{l}\text { Renewable energy } \\
\text { Energy laws }\end{array}$ & $\sqrt{ }$ & & $\sqrt{ }$ & {$[26]$} \\
\hline Calculation Modelling & $10^{\text {th }}$ Five-Year Plan & $\sqrt{ }$ & $\sqrt{ }$ & $\sqrt{ }$ & [42] \\
\hline Calculation Modelling & $\mathrm{CO}_{2}$ reduction policy & $\sqrt{ }$ & $\sqrt{ }$ & $\sqrt{ }$ & [43] \\
\hline Calculation Modelling \& Mapping & Energy conservation policy & $\sqrt{ }$ & $\sqrt{ }$ & & {$[44]$} \\
\hline Questionnaire Survey & Clean development mechanism & $\sqrt{ }$ & $\sqrt{ }$ & $\sqrt{ }$ & [45] \\
\hline
\end{tabular}

Also a series of studies related with China BEES have been selected and analysed for the verification, as shown in Table 3.

Table 3

Review of building standard studies with different research methods

\begin{tabular}{|c|c|c|c|c|c|}
\hline Evaluation Method & Research area & Target standard & Building Type & Climate Zone & Reference \\
\hline Content Analysis \& Statistic Review & Energy & $\begin{array}{l}\text { GB 50178-93 } \\
\text { GB 50189-2005 }\end{array}$ & $\begin{array}{l}\text { Public and } \\
\text { residential }\end{array}$ & National & {$[46]$} \\
\hline Content Analysis \& Statistic Review & Energy & All & $\begin{array}{l}\text { Public and } \\
\text { residential }\end{array}$ & National & $\begin{array}{l}{[18],[47],} \\
{[48],[49]}\end{array}$ \\
\hline Content Analysis \& Statistic Review & $\begin{array}{l}\text { Energy and } \\
\text { design }\end{array}$ & $\begin{array}{l}\text { GB 50189-2005 } \\
\text { GB 50189-2015 }\end{array}$ & Public & National & {$[50]$} \\
\hline Content Analysis \& Comparison & Energy & GB 50189-2005 & Public & HSCW & [19] \\
\hline Content Analysis \& Comparison & Energy & $\begin{array}{l}\text { GB/T51161-2016 } \\
\text { GB 50189-2015 }\end{array}$ & Public & National & {$[20]$} \\
\hline Statistical Calculation & Energy & $\begin{array}{l}\text { GB 50189-2005 } \\
\text { JGJ 75-2003 }\end{array}$ & $\begin{array}{l}\text { Public and } \\
\text { residential }\end{array}$ & $\begin{array}{l}\text { SC, C, HSCW, } \\
\text { HSWW }\end{array}$ & {$[51]$} \\
\hline
\end{tabular}


Table 3

Review of building standard studies with different research methods

\begin{tabular}{|c|c|c|c|c|c|}
\hline Evaluation Method & Research area & Target standard & Building Type & Climate Zone & Reference \\
\hline & & JGJ 26-2010 & & & \\
\hline Statistical Calculation & Energy & GB/T51161-2016 & $\begin{array}{l}\text { Public and } \\
\text { residential }\end{array}$ & National & [52] \\
\hline Statistical Calculation & $\begin{array}{l}\text { Indoor thermal } \\
\text { environment }\end{array}$ & $\begin{array}{l}\text { GB/T 50785-2012 } \\
\text { GB 50736-2012 }\end{array}$ & Public & National & {$[53,54]$} \\
\hline Case Study \& Data Investigation & Energy & GB 50189-2015 & Public - office & $\mathrm{C}$ & [55]. \\
\hline Case Study \& Data Investigation & Energy & GB 50189-2015 & $\begin{array}{l}\text { Public - } \\
\text { commercial }\end{array}$ & $\begin{array}{l}\text { C, HSCW, } \\
\text { HSWW }\end{array}$ & {$[56]$} \\
\hline Case Study \& Data Investigation & Energy & $\begin{array}{l}\text { JGJ 26-2010 } \\
\text { JGJ 134-2010 } \\
\text { JGJ 75-2012 }\end{array}$ & Residential & National & [49] \\
\hline Case Study \& Calculation Modelling & Energy & JGJ 75-2012 & Residential & HSWW & [57] \\
\hline
\end{tabular}

\section{Before 1995: Aggressive Development}

Issued by National Development and Reform Commission (NDRC), the Five-Year Plans (FYPs) are the foundation for national policy. They are designed to set out the strategic direction of how the country will operate over the forthcoming five-year period. They hence provide invaluable sources of data in terms of the espoused top-down policy vis-a-vis energy, building and environment issues. There is however an under-utilized resource for researchers. The detailed review analysis is listed and can be found in Appendix A. It is found that before 1995, FYPs were the only national policy package which contains energy and building content [58].

However, during 1986 to 1995, the major task was to develop the economy. During this time, energy growth was the most important index with clear objectives [59]. This period could also be defined as 'aggressive mode' of national development of the $7^{\text {th }}$ and $8^{\text {th }}$ FYP focused attention only on economic growth. Increasing coal and oil consumption were hence considered as a means to an end without any consideration of their environmental impact. Environmental protection was only rarely discussed during this period [58]. The dominant modus operandi seemed to be 'damage first and repair later'.

This shows that the governmental policy system in China has been constructed over the last 20 years and despite the progress made it continues to have many problems. A series of studies [35], [34], [26, 37-41] have reviewed and analysed the China GPEBE system at various stages of its development. Yao et al [34] and Huang et al. [41] criticize the slow speed at which local energy efficiency regulations have been issued. As a negative result, there are still massive amount of buildings exist today built during this period with very poor building performance parameters, which brings extreme pressure for building retrofit career. 


\section{1995-2010: The Transition}

\subsection{The $9^{\text {th }}$ to $11^{\text {th }}$ Five-Year Plans}

The period of 1992-1994 immediately prior to China joining UNFCCC is best described as 'transitionary' whereby the previous 'aggressive mode of development' was progressively modified with increased consideration of environmental impacts. Although the international protocols of climate changes remain heavily contested, they undoubtedly provided the impetus for the 'energy-saving and emission-reduction' programme initiated in the 1995 Five-Year Plan. From 1995, as the global background to energy growth changed, China started to consider issues of environmental pollution [60]. This was in part driven by events as such problems were becoming all too apparent. Issues were not limited to air pollution but also included the pollution of water resources and the legacy of toxic brownfield environments.

Simultaneously, the 1998 Asian Financial Crisis created significant shock to the national economic development. Economic development notably slowed down for a short period of time around 1998 [61]. After 2000, China's development strategy was adjusted to 'sustainable development' [62]. These years were characterised by a significant re-focusing of the policy agenda onto the twin themes of such as 'repair of damaged natural environments' and 'optimisation of the energy systems. Issues relating to 'environment and sustainability' were notably added into the FYPs, with a vast array of objectives set to reduce energy consumption, polluting emissions and the repair the nature environments. Arguably, there is another problem that the FYPs are still too general for detailed local use, as stated by Kong et al. [35] who have comprehensively reviewed all the important GPEBE issued during the $11^{\text {th }} \mathrm{FYP}$ period. It argues that ECPB is only routinely related to single buildings, rather than to different urban zones or even clusters of buildings within different climate zones.

\subsection{National Notices and Actions}

In 2005, the central government started to issue a new type of small-scale policy strategy which is enacted through national notices and governmental actions. In the name of the State Council (GOV) and the Standing Committee of the National People's Congress (NPC), this new type of policy aims at reinforcing the policies expressed in the FYPs. and to strengthens the applicability and supervision of FYP objectives. They notable provide more detailed guidelines in terms of how the policies should be implemented.

In the $11^{\text {th }}$ FYP, the State Council started to create the detailed plans called 'national actions' relating to specific areas. It represents a very important step beyond what was offered in previous FYPs [63]. The increased level of detail content made it much easier for both relevant research institutes and privatesector enterprises to adjust their operational strategies accordingly. It is perhaps worth emphasizing that in China there is a much stronger expectation that operational managers should align themselves with topdown policy objectives than prevails in the West.

The national notices that relate to the three development aspects of energy, building and environment sectors from 1980s until today are listed in Appendix B. 


\subsection{The beginning of ECPB Laws}

The first energy conservation law in China was notably established in late 1997, which is some 10 years after the first building energy standard. Driven by political forces and implemented through the imposition of penalties, laws are usually the strictest measures used in China to reinforce the implementation of policy $[64,65]$. In this section, relevant energy and sustainability laws issued by the National People's Congress and its Standing Committee (NPC) are reviewed and analysed (see Appendix C). Hence legislation in support of energy and sustainability in China is relatively young comparison to Western countries. For example, the development of energy conservation legislation in the UK can be traced back for more than 40 years [66].

Given the relatedly recent introduction of energy-related legislation in China it is unsurprising that it is often less than perfect. Indeed, two critical shortcomings can be found in energy laws development - one is too general law clauses without related supervision and penalty measures. As in the first energy conservation law issued in 1997, only broad words such as 'cannot' and 'should not' have been presented for the actions against the energy conservation regulations [67]. However, it remains almost impossible to impose the stipulated penalties because of the lack of connectivity with civil law. Majority of paper from Kong et al. [35], Liu [65], Yao et al. [34], Zhang and Wang [37], Cai et al. [38], Huang et al. [41] mention this point that existing legislation is not strong enough to enforce the implementation of ECPB. Therefore, this problem has led to the energy legislation issued in the early years failing to fulfill its specified function of controlling energy waste and pollutions - such legislative failures are of course not limited to China, as evidenced by the ill-feted 'Green Deal' in the UK [68]. After almost ten years, the situation in China has been improved by the introduction of new legislation [69-71], and previous legislation has also been re-issued with added tax incentives and penalty measures [72].

\subsection{The pioneer: BEES of residential buildings}

Issued by MOHURD as detailed building engineering regulations, all BEES content during last 40 years have been reviewed, listed and discussed in Appendix D. Historically, industrial buildings were firstly applied with HVAC system standard, but the residential and hotel building type were the pioneers of energy conservation standards [73]. For the first time, JGJ 26 issued in 1987: Design standard for energy efficiency of residential buildings in severe cold and cold zones, is the milestone of China's BEES development with a $30 \%$ energy conservation rate was set compared with 1980 s residential buildings. Improving the efficiency of boilers and system of heating stations was the biggest consideration in 1987 and 1995 (energy conservation rate improved to 50\%) version of this standard [74].

For Southern China, JGJ 134: Design standard for energy efficiency of residential buildings in hot summer and cold winter zone. This BEES of the HSCW zone issued in 2001 focused more on cooling equipment efficiency, shading and natural ventilation. Meanwhile, their requirements of design parameters are more complicate with adaption of local people behavior habits and climate conditions. In the newest version of JGJ134, the minimum requirements of building envelope such as $U$-value and infiltration level have also been much improved [75].

Similarly, JGJ 75: Design Standard for Energy Efficiency of Residential Buildings in the Hot Summer and Warm Winter Zone, released in 2003, could be seen as a special version of JGJ134 with less content of 
heating, but more approaches to solve problems of high temperature in summer [76], such as energy conservation techniques in indoor air-conditioning. Considering overheating issues, JGJ75 has very flexible rules in building envelope designs, but many unique mandatory requirements in shading, dehumidification and ventilation, which are reasonable based on the weather condition this standard apply [77], but same as others, this standard has not been upgraded for 6 years.

\subsection{The beginning of mandatory rules: BEES of public buildings}

Statistics showed that the number of public buildings in China was annually increased to 500 million $\mathrm{m}^{2}$ in 2015, and that they consumed 7.5-15 times more energy than residential buildings [2], [78]. This may imply poor designs and operation methods in terms of energy efficiency, or it may imply that they end up being used in different ways to those envisaged. Therefore, the MOHURD has paid massive attention for energy efficiency career to public buildings [28], and this comprehensive building regulation could be considered as the most successful BEES package during the development of ECPB in China.

GB 50189: Design Standard for Energy Efficiency of Public Buildings, is the key and first mandatory BEES for China's public buildings. Although it was a very poor HVAC design code for tourist hotels in 1993 [73], this standard has successfully reduced $50 \%$ of energy consumption in new constructed public building sector [50] in 2005. Its $2^{\text {nd }}$ edition in 2005 contained massive detailed index, information and approaches of calculation and application installation including building envelope in different climate conditions, lighting, HVAC equipment, occupancy behavior schedule, water system, and renewable energy applications [28]. This standard had become a reasonable template for further upgrades of residential building standards, had ended the old experience-relied design, and had made a good example which the other previous standards were too general. Furthermore, this standard had investigated the building information parameters of old buildings built around the 1980 years and made them as the baseline model for the further building retrofitting research.

\section{After 2010: Sustainable Development of Energy and Buildings}

\subsection{The $12^{\text {th }}$ and $13^{\text {th }}$ Five-Year Plans}

Thereafter, in the $11^{\text {th }}$ FYP period of 2005 to 2010, the 'Energy-Saving and Emission-Reduction' strategy was formally confirmed by the State Council as the key theme of China's development [63]. The energy conservation objectives in the $11^{\text {th }}$ FYP were far more ambitious than there were in the $10^{\text {th }}$ FYP. Considerable emphasis was also placed on renewable energy. The expressed commitment to repairing and improving the damaged environments are even stronger in the most recent national policies, the $12^{\text {th }}$ and $13^{\text {th }}$ Five-Year Plans. In the building energy sector, the emphasis lies on improving the quality of the buildings in both urban and rural area. As a result, there was a boom in the number of policies, regulations and standard updates for new construction buildings and building retrofitting, which majority of them have higher objectives in energy-saving. 


\subsection{Improved energy and building laws6.3. Development of mandatory BEES}

From 2010, as the energy conservation rate was further increased to $65 \%$, there were more attentions paid into the building thermal performance index including building envelope $U$-value and air-infiltration. However, many mandatory has not been received any updates for years before 2010, and many design parameters are no more reasonable for today's energy conservation objectives. Later, the revision of JGJ 26, JGJ 134, JGJ 75 of mandatory residential building BEES all state for even more restrict rules, asks for a $15 \%$ to $30 \%$ more energy conservation rate compared to their old version [28],[75],[76]. Furthermore, these BEES started to clarify the building shape factor and window-to-wall ratio as mandatory index for building design, which proved the firm national development strategy of "energy saving and carbon reduction". Likely, in 2015, the GB50189 was updated to achieve 65\% reduced energy consumption [2].

Moreover, in 2013, it was the first time that rural building and building retrofit have received attention from the BEES. GB/T 50824: Design Standard for Energy Efficiency of Rural Residential Buildings is the first national standard mentioned energy conservation in rural residential buildings [79]. This unique code is suitable for rural houses which have difficulties to reach the strict urban BEES due to complex social and economic reasons. Meanwhile, JGJ/T 129: Technical Specification for Energy Efficiency Retrofitting of Existing Residential Buildings is a first general standard for energy efficiency retrofitting, but many of its index and evaluation method are based on current residential new building standards. These standard have much less requirements both in amount and quality of energy conservation measures and design parameters than other urban new building BEES.

\subsection{Integrated advanced BEES}

The integrated BEES issued in the world are multifarious in measures, objectives and key aspects, and in China, it was firstly introduced in 2006 but rapidly improved till 2010 as JGJ/T 229-2010, to introduce the concept of green buildings. Likely as BREEAM and LEED standards, JGJ/T 229 and GB/T 50378: Assessment Standard for Green Building, is the China's green building assessment code that provides fundamental information of evaluation method, called 'China Green Building Label (CGBL)' in 2006. With a 16 years late than the UK's BREEAM from 1990, the CGBL was only a design-stage code with very general and simple content in 2006 when it was born. During the beginning of CGBL, majority of credits were given based on the GB 50983-2005 standard and old residential BEES, by simply asking 5\% or $10 \%$ improved building parameter settings higher than these codes.

During 6 years, CGBL has been swiftly developed as 742 demonstrative building projects with 75 million $\mathrm{m}^{2}$ building area [80]. In its 2014 version, there were massive content such as building operating assessment, lots of additional credits, and many improvements of evaluation methods added to make this CGBL tool became much more reasonable to be used. In 2019, the newest version of green building assessment code is issued, with a new credit index of "extra score" applied. This extra score allows building designs to use even more advanced measures of building energy conservation and sustainability beyond the governmental BEES, to reach a higher total green building score and get relevant financial and reputation supports [81]. Together with GB/T 50668-2011: Standard for Energy Efficient Building Assessment [82], they could be proof of related national financial support or energy discount measures.

More recently the Technical Guidelines of Passive, Ultra-low energy consumption, and Green buildings 
(TGPUG) is an official technical guide presented in 2016 which started the new concept of using integrated techniques. This under-testing guideline focus on using integrated approach of combining passive design, high efficiency techniques and green building thinking to acquire the best goal of both the energy efficiency and sustainability. It uses the German Passive-House standard as the reference, as much increased building envelope $U$-value and air tightness compared with current national BEES, and uses green building assessment standards for land, water and energy saving purposes [83]. Later, GB/T 51350-2019, as called Technical Standard for Nearly-Zero Energy building (TSNZE) in design stage, is the newest BEES. This new standard raised the definition of "China's nearly-zero energy building" which requires about $60 \%$ $70 \%$ reduced energy consumption based on the current public and residential BEES [84].

\section{Discussion}

Supported by above sections of comprehensive review of ECPB, in this section, the detailed discussion is presented to analyse the ECPB milestones, historical development, policy achievements, policy barriers and suggestions.

\subsection{A Clear Picture of ECPB Historical development}

By summarizing the GPEBE and BEES reviewed in previous sections, the implementation numbers of ECPB development in China could be performed a figure shown below as Figure 2. It shows the implementation situation of ECPB in both numbers and time during the last four decades. From the figure, it is easily found that the frequency of new published and revised ECPB have a significant boundaries during the timeline between $10^{\text {th }}$ to $11^{\text {th }} \mathrm{FYP}$, and $11^{\text {th }}$ to $12^{\text {th }} \mathrm{FYP}$.

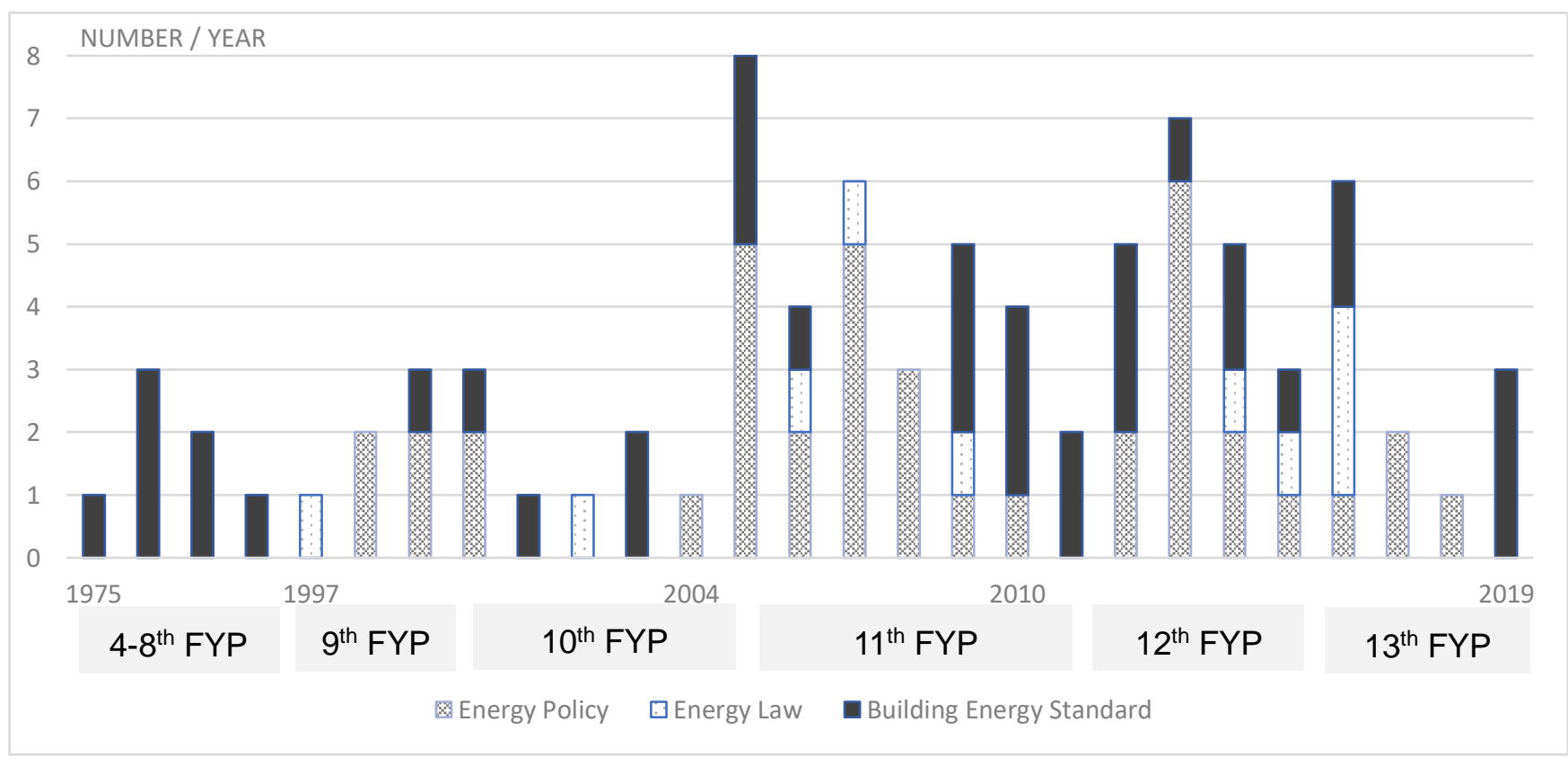

Figure 2 Number of energy policies, laws and standards issued during China's modern development from 1975 to 2018 
To discover the milestone ECPB in the historical view, in 1987, the BEES for civil residential buildings were started to be divided as specific climate-respond standards in Severe Cold (SC) and Cold (C) climate zones; 2001 for Hot Summer and Cold Winter (HSCW) climate zone; and 2003 for Hot Summer and Warm Winter (HSWW) zone. So, for the first time of considering climate-respond design measures in building energy, the JGJ 134-2001 standard was a milestone of residential BEES during the China modern development.

For public buildings, however, the milestone arrived a later. In 2005, GB 50189, the first comprehensive BEES of public buildings finally started its function to control the energy consumption of buildings constructed without any official BEES. The standard ambitiously covered all five climate zones of China and almost every different type of public building. It was however nuanced enough to include energy conservation measures that were not evident in previous BEES, such as occupancy profile control and smart lighting control. The standard also included variety of climate-respond design measures. This method of localized thinking was further developed in first green building standard of China issued in 2006.

Much later, followed the new policy system of national notice and actions from $11^{\text {th }}$ FYP, JGJ/T 229-2010: Code for Green Design of Civil Buildings was issued as a design code specifically for the new green buildings. This was a more comprehensive standard which introduced the distinction between 'passive techniques', and 'active techniques. It was also notable for establishing the concept of 'green design' in building thermal environments, HVAC and lighting system [85], which was further developed in the BEES of China passive housing. This latter code also emphasizes the importance of the building whole life cycle which was also reference of 2014 revision of GB/T 50378 green building standard.

Accordingly, the milestone ECPBs concluded could be summarised below in Table 5. The milestone ECPBs could be supported and discovered, hence a more detailed classification of development stages could be clearly defined.

\section{Table 5}

Milestones of ECPB development in China

\begin{tabular}{|c|c|c|}
\hline Milestone events / policies & Year & Description \\
\hline Energy conservation law & 1997 & First national energy conservation law \\
\hline Asian Financial Crisis & 1998 & $\begin{array}{l}\text { External factor that cause economic and energy shortage issues - changed the } \\
\text { national energy development strategy to 'increasing generating annually' to } \\
\text { 'reducing energy consumption and waste annually' }\end{array}$ \\
\hline Kyoto Protocol & 1998 & First global protocol in climate change and GHG emission reduction \\
\hline The $10^{\text {th }} \mathrm{FYP}$ & 2000 & $\begin{array}{l}\text { First time mentioned "energy-saving and emission-reduction" as national } \\
\text { development strategy }\end{array}$ \\
\hline National notice and actions & 2005 & $\begin{array}{l}\text { New government system to give quick order and feedback to the Five-Year } \\
\text { Plans }\end{array}$ \\
\hline GB 50189-2005 & 2005 & First comprehensive energy conservation design code for public buildings \\
\hline The $11^{\text {th }}$ FYP & 2006 & $\begin{array}{l}\text { First time presented 'sustainable development' as basic nation development } \\
\text { strategy }\end{array}$ \\
\hline Renewable energy law & 2006 & First official renewable energy law \\
\hline JGJ/T 229-2010 & 2010 & $\begin{array}{l}\text { First comprehensive green building design code with engineering measures, } \\
\text { rather than credit assessment tools }\end{array}$ \\
\hline The $12^{\text {th }}$ FYP & 2011 & Massive content in energy conservation of building, energy and environment \\
\hline
\end{tabular}

Based on the chronological review of ECPB content, history, relevant studies and milestone analysis from above sections, a clear grand picture of China ECPB historical development can be therefore generated, and it is finally classified as four stages during the studied timeline, presented as Figure 3. 
Governmental Policies of

Energy, Building and Environment

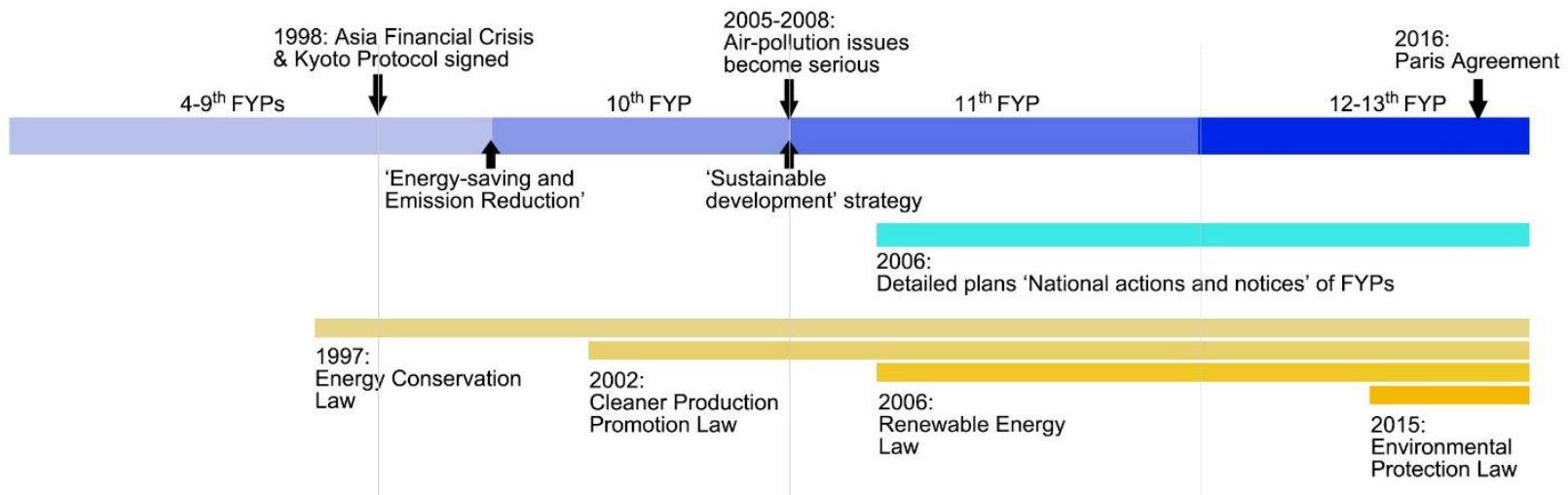

Building Energy Efficiency Standards

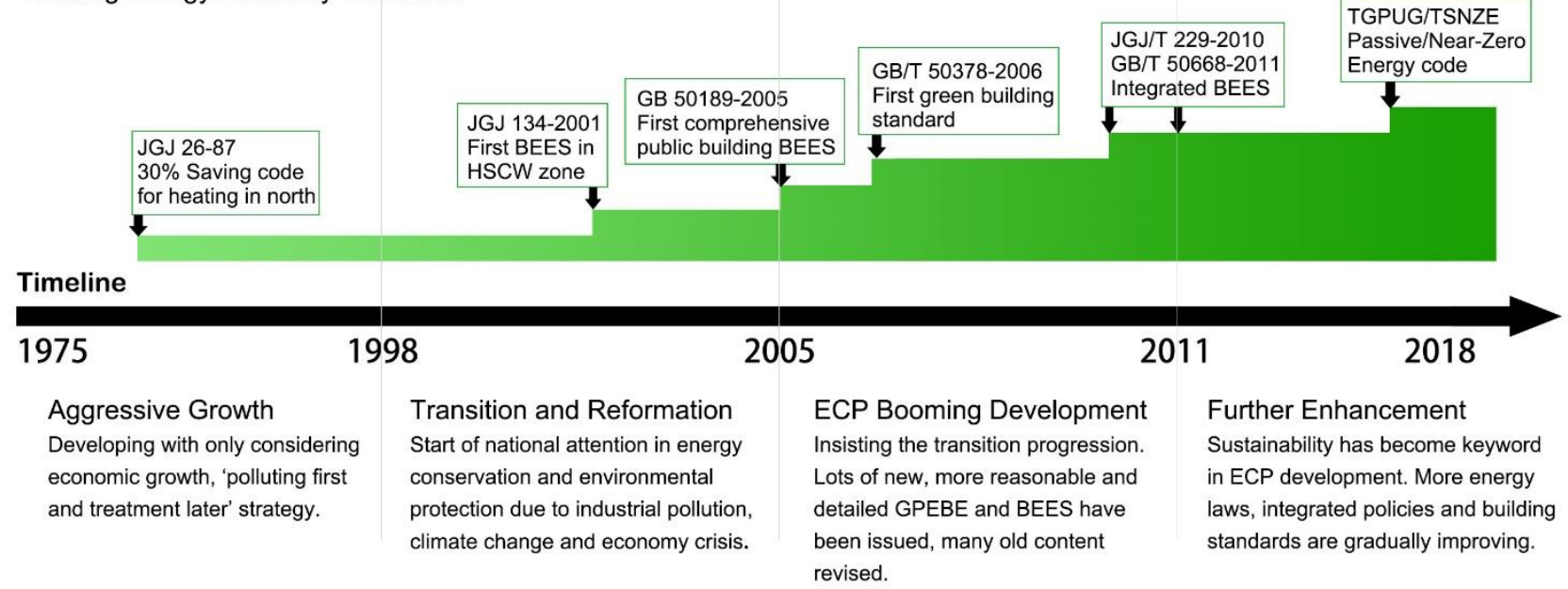

Figure 3 Chronology of ECPB development and ECPB milestones

\section{1) 1975-1997: Aggressive growth}

From the reviews of the ECPB objectives in the previous section, it could be found that before 1998, Chinese government paid major attention on developing energy industries, GDP, number of buildings, with an unsustainable strategy of 'polluting first, treatment later'. Although there were several encouragement policies of energy conservation and renewable energy in $7^{\text {th }}$ to $9^{\text {th }}$ FYPs, their objectives were too general. The first energy conservation law was issued by the NPC in 1997, was not very effective in aspect of controlling energy consumption. Also, its broad and general description of concepts and no designated governmental offices had resulted in an embarrassing position of powerless for many years [86]. Therefore, this aggressive strategy of development had planted the problematic seeds of energy and pollution, which had significantly affected the ECPB development in the later years.

\section{2) 1998-2004: The transition and reformation}


With the energy and pollution problems appeared and agreements signed on the Kyoto Protocol in 1998, it could be regarded the symbol of the transition of the changing of the development strategy to the 'sustainable mode'. The governmental policies of nation development had started to consider the energy-waste caused by economic and environmental reasons instead of blindly chasing higher objectives of industry achievements and GDP. This transition and reformation thinking brought valuable sustainable ideas and changes in energy and building policies, improvements of many old, general energy and environment laws, new editions of old building standards, and the $10^{\text {th }} \mathrm{FYP}$ with many new sustainable concepts had become the very foundation of future national development strategy reformation.

\section{3) 2005-2010: Booming ECPB}

Driven by the issues of national energy shortage, air-pollution and climate change, China insisted the reformation progress and has stepped into the stage of booming ECPB development during the $11^{\text {th }}$ FYP period. The implementation of the first comprehensive national BEES [28] could be seen as the most important symbol which demonstrated the determination of China's strategy transition. More importantly, the improvements in relevant laws have received major updates, more details and closer connections with civil and criminal laws had made these laws become much more powerful to illegal activities and projects against the ECPB and BEES.

\section{4) 2011 and later: Further enhancement}

The ECPB development continues following the energy-conservation and pollution-reduction method after the transition. By reviewing the content in the $12^{\text {th }}$ and $13^{\text {th }}$ FYPs, it could be found that the $11^{\text {th }}$ FYP had been used as an excellent template due to its more detailed, reasonable objectives and approaches in energy conservation and environment protection. Furthermore, with more completed establishment of legislative and execution system, the previous important energy laws had received major updates including energy conservation law, renewable energy law, and new environmental impact assessment laws. Also, new environmental protection tax law was implemented followed to further improve the legislation control. Accordingly, the enhanced ECPB had shown their essential roles in further improving stage of building energy conservation and sustainable development.

Besides, with the quantity of the ECPB issued is increasing, the quality of ECPB in China is also palpably improving after the transition of development mode. The FYPs now is having more detailed objectives and practical guidance; the national notices and actions are issuing more frequently to further provide directions to ECPB followers; the energy laws are revised much timelier, and the BEES are being added with more modern integrated energy conservation thinking and techniques. As a result, the progression of ECPB development is on an optimistic path.

\subsection{Policy Achievements}

Supported by the content reviews and analysis of the ECPB as well as relevant published researches presented in this study, the achievements of the GPEBE and BEES mechanism are analysed and could be summarized below as four key points.

\section{1) Establishment of ECPB system}

Policy system is effective but difficult to fully present its power to promote energy conservation due to 
the complexities of the country's numerous populations, land area and types of climate, culture and social conditions. Thus, the policy system of large-scale countries needs to be efficient and powerful in authority and executing capacity.

By comprehensively reviewing almost all important ECPB issued during the period of modernisation, it has been found that China has chosen the 'top-down administrative method' for ECPB system and established a systemic policy system for energy conservation and environmental protection career. Also, revising antiquated GPEBE and BEES has become a common progression every year. Furthermore, the national notices and actions have proven as a great approach to optimise the familiar problem of 'too general content' in Five-Year Plans and 'too long period' in revising energy laws for its quick-responding effect.

\section{2) Continuously insistent policies of energy conservation from the central government}

From choronogical review, it is found that 'Energy-saving and emission-reduction' is continuously presented until today in every national energy policy after 2005. Historically, during the ECPB development, Chinese central government has presented a very strong statement of 'transition and reforming' to change the previous 'aggressive mode of energy development' into 'energy conservation and sustainable mode' in $10^{\text {th }}$ and $11^{\text {th }}$ FYPs. As great determination made effects, recently, every single clause of ECPB has mentioned this national strategy, which are frequently reminding all energy industries and construction enterprises to bear in mind about energy conservation.

\section{3) Improved and more detailed progression}

Based on the content reviewed of BEES development timeline, the building design index, energy conservation measures, and building energy conservation applications are improving and becoming more comprehensive. It is evidenced that BEES have received gradually improvements by more detailed and scientific revisions, as well as more considerations to introduce new thinking of comfort and sustainability. For example, the thermal requirement of building envelope set in BEES have been progressed gradually in each revision and updates, such as more considerations were added in [2] including number of floors, sub-climate conditions under the five base climate zones, and shading approaches in hot summer zones.

\section{4) Effectiveness in building energy efficiency and sustainability}

Most importantly, the effectiveness of energy conservation promoted by ECPB is also proven appreciable from other researchers. Peng and Liu [24], Huo et al. [30] used top-down calculation method based on the national statistics, estimated an increase from $17.7 \%$ to $20.3 \%$ in terms of energy efficiency in the building sector due to GPEBE implementation. Jiao and Boons [25] used both statistical calculation and a case study method to translate the circular economy policies and showed their results in energy conservation. Furthermore, Chai and Zhang [42] provided different scenarios of ECPB transitions in $10^{\text {th }} \mathrm{FYP}$ and made projections of their effectiveness till 2050 , showed a $25 \%$ $\mathrm{CO}_{2}$ reduction in 2020 and over $50 \%$ rate of renewable energy usage could be reached in 2050 . Yuan and Zuo [39], Tan et al. [43] present a review of GPEBE clauses and statistics, they acquired the reduction and 2050 projection data of carbon emission effectiveness, while [43] simulated and admired the progression of current ECPB which can reach the objective of $50 \% \mathrm{CO}_{2}$ reduction in 2046 , 4 years before the 2050's target.

Li and Shui [18], Huo et al. [47], CABEE [49], Zhang et al. [52] also used top-down statistical 
calculation method to evaluate the ECPB effectiveness. CABEE [49] argues that the application of BEES has resulted in significant reductions in energy usage. The claim is that the period 2007-2014 saw a $10 \%$ annual energy reduction rate in urban public buildings, $5 \%$ in urban residential buildings, and a 53\% total energy reduction rate in district heating system used in north China area. Yu et al. [51] also gave a long term $\mathrm{CO}_{2}$ projection view from 2005 to 2095 , stated a $13 \%-22 \%$ national $\mathrm{CO}_{2}$ reduction caused by BEES' effort.

Scholars also used case study methods to provide examples of BEES effectiveness in the investigated buildings. Wei et al. [55] developed a city-level BEES benchmarking system, investigating 88 office buildings in one city and evaluating their energy efficiency. Yet their results indicate a rate that BEES requirements were only partly applied in majority real projects. Also papers provided by Huo et al., Guo et al., and Chen et al. [56, 57, 87] take several cities as case studies, investigated and analysed their urban statistics to get the success of energy conservation effects from BEES.

Accordingly, the effectiveness of the 'top-down administration' method of ECPB contributed largely to the achievement of country's carbon emission reduction target, however, there are still many problems appeared within them, which are discussed in the next section.

\subsection{Barriers and Suggestions for the Next Stage}

During the fast growth of ECPB development, there are also many limitations and shortcomings discovered from the review and analysis of ECPB content and studies. After reviewing the ECPB development of their content, the main problems found are pointed out as below in six parts. Accordingly, the fifth stage - 'the entrie improvement' stage could be expected as the next stage of China's ECPB development in the future, by applying suggested solution measures to overcome all aboved disscsued policy barriers.

\section{1) Frequency of policy update}

As the most intuitive issue, frequency of policy update is a big concern for China ECPB's future career. There is a figure which can show the updating frequency situation of China ECPB so far as below in Figure 4. 


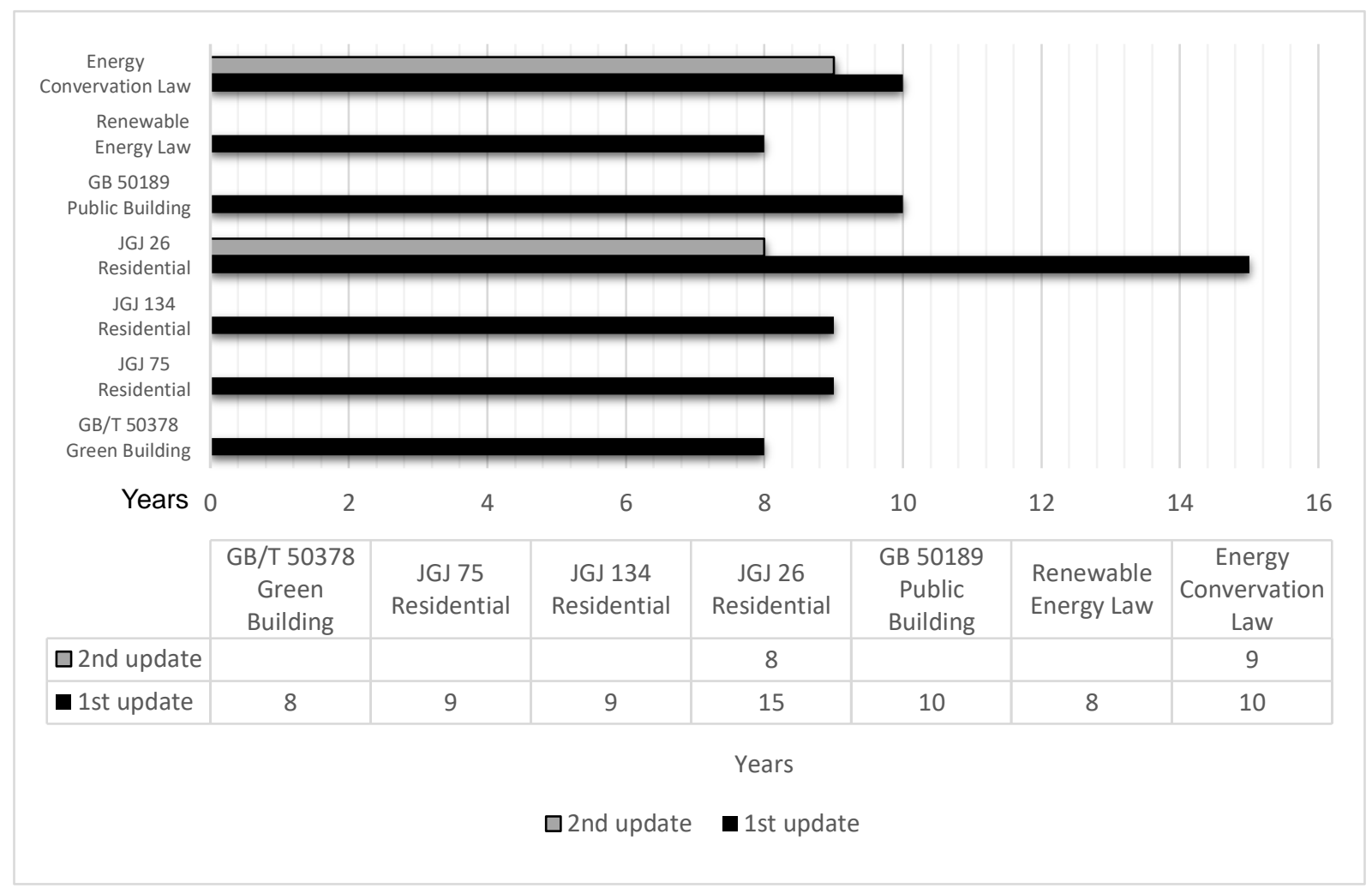

Figure 4 Years taken for the ECPB update (number 0 to 16 on the figure)

From the figure we can see that the gap of updating the ECPB was very long, as at least 8 years for a single law or BEES to receive an amendment. For example, the JGJ 26 about district heating system was updated in 2010 after it was firstly issued in 1995. Furthermore, the JGJ 26 and JGJ 134 have not been updated for 8 years since the last issue, with many building parameters have become antiquated. Therefore, it is urgent to have a new appropriate BEES to suit the current situation of higher energy efficient demand in residential buildings and heating system.

Compared with other developed countries such as the UK's BEES, there is approximately one version of amendment issued each year. Although it might not be necessary to update the ECPB too frequently, many studies reviewed have still pointed out that the current ECPB update are not timely which seems to be cumbersome in contrast with rapidly created and improved energy efficiency technologies. Accordingly, accelerating the effectiveness of ECPB system means there will be more appropriation for relevant manpower of governmental workers and energy researchers, and this is helpful to increase the ECPB supervision strength simultaneously, by developing the method of ECPB administrations. Referencing the UK's practice of using energy performance label in each single building of the country [66], it could referenced if this be an appropriate supervision approach, similar as the energy statement mechanism mentioned by many studies [49, 87].

Meanwhile, more researches with ECPB administration analysis would be valuable - rather than general statement as 'lack of supervision' in many research papers, there is also only little researches with statistical analysis similar as study [48] that provided exact data of ECPB supervision situation. On this point, studies with statistical analysis of ECPB implementation circumstance would be very helpful for policymakers to find their working focus and direction of endeavor. For example, it was proved by studies that China's urban BEES for new buildings have successfully reached the $100 \%$ 
implementation rate in 2012 from only 54\% in 2006 [48] with intensive political controls in construction management. Similarly, policy-makers could apply the similar approaches to increase supervision strength of new testing, retrofitting, and voluntary BEES.

\section{2) Supervision of policy implementation}

As a top-down administrative control, public policies can be very powerful and effective, but also could be the useless blank slate if no governmental forces of regulators to execute the content, rules, and implementation rate from relevant administrative institutions [88]. Furthermore, guaranteed policy implementation effectiveness is fundamental for majority of building energy researches - it is easily found that majority scholars calculate the policy effectiveness with a "default hypothesis" which buildings are built completely following current ECPB, and most of building energy simulation studies have designed their building characterizes from policy content of BEES.

However, it is not rare to find that the policy was implemented but not fully applied to the reality [88]. Guo et al. [48] is valuable which provide statistical supported data of ECPB supervision situations. It was suggested that critical problem prior to 2012 related to the extent to which BEES was fully applied. This study showed that there was only $21 \%$ compliance rate in the construction stage in 2005 , later it was gradually increased as $54 \%$ in $2006,71 \%$ in 2007 , and $82 \%$ to $100 \%$ from 2008 to 2012 . Liu et al. [32] analysed the demonstration projects for renewable energy applications, stating that the incentive award mechanism for both energy conservation and renewable energy institutes is the best approach to quicken their development. Zhang et al. [31] surveyed buildings under the use of Energy Performance Contracting (EPC). It focuses critical attention on the problems of current EPC policies such as low specificity, not enough further investment, and no proper building maintenance because of insufficient policy supervision.

As it is a global challenge to effectively and fully apply the designed policy to reality [5], it is important to further improve the strength of ECPB supervision and management, in the way such as improve the frequency of building energy efficiency inspection and reporting, or increase the power of controlling laws, monitoring, and examinations. The reviews have shown that the early ECPB including the FYPs, energy laws, and building standards had problems with too general content, which made them difficult to be followed and supervised. With the development of ECPB in recent years, this issue has been gradually solved by revising old ECPB. However, as the ECPB now become stricter for the energy and building industries, the supervision of ECPB still needs enough political attention to force their implementation with sound financial support or penalty measures.

\section{3) Local-respond policy}

Considering unique local strength and conditions in aspects of local climate, social and energy resource condition is essential to achieve higher energy conservation effectiveness of ECPB in a large country scale. The current ECPB are still not comprehensive enough with individual local situations. Regional variation in ECPB studies from previous studies, Zhou et al. [45] suggests establishing a mechanism which incentivizes clean development and creating regional building energy indicators to monitor local policy administration. Zheng et al. [44] further mapped the efficiency of ECPB measures based on data envelopment analysis with energy companies, highlighting the importance of diverse climate conditions of regions that affected the ECPB effectiveness, which are helpful for the development of localized responses.

Besides, there are many studies have discussed the advanced techniques of energy sustainability 
which may further enhance the BEES effects based on unique local conditions. Li et al. [53], and Li et al. [54] evaluated the BEES with indoor thermal comfort characteristics, estimating the adaptive occupancy behavior of 'free-running buildings' could be considered in BEES which may become a path to further increased the energy conservation effects. Later, this statement is supported by Yao et al. [4] which applied passive design measures to extend the non-heating and cooling period to achieve a $18 \%-24 \%$ energy conservation effect in HSCW climate zones.

In new integrated BEES issued, more local designs, including climate-responding design in building envelope, shading and HVAC equipment, and behavior-responding design in lighting controls are added into the design rules. It can be inferred that the ECPB system is taking more local condition responding thinking into account. Additionally, combined with considerations of local conditions, specifying the climate conditions and resource advantages with meticulous and detailed climate zones can be helpful for local governments to use.

\section{4) Renewable energy progression}

Another possible improvement is the progress of renewable energy development. In FYPs, the objectives of renewable energy share were gradually increased from $1.8 \%$ in 2006 to $11.4 \%$ in 2011 and to $15 \%$ in 2016 , but it was still a 'predicted' target rather than other tough mandatory goals, without enough detailed ECPB content to help to achieve them [65]. Therefore, there should be more powerful policies in renewable energy and sustainability, including centralized policy and incentive financial support for related market.

Comparatively, the Renewable Energy Directive (RED) in the European Union and the Renewables Obligation (RO) and the United Kingdom have both significantly improved the renewable energy development by mandatorily set certificate requirement rules to energy suppliers to increase the share of electricity generated by renewable energy resources. From the reports, RED was proven that the European Union has increased it average renewable energy share from $8.5 \%$ in 2004 [89] to $17 \%$ in 2016 [90], and a revised objective has been set as $27 \%$ target for 2030 . The $\mathrm{RO}$ in the UK has also shown its effectiveness of percentage of supply from 3\% in 2002 to $15.4 \%$ in 2016, and a further high target in 2037 [91]. Similar as EPC method, studying this legislative-certificate approach would be useful for ECPB-makers to consider about how to improve the sustainability for China's future.

\section{5) Building energy efficiency retrofit}

Because of energy conservation development in residential buildings started in 1995 for only heating in $\mathrm{SC}$ and $\mathrm{C}$ zones, it brought a circumstance that a vast number of existing buildings were built with poor thermal performance materials and now still remain low energy efficiency. Moreover, energy retrofitting objectives are on less important stage in the FYPs, either the BEES of retrofitting [78] have least content and less mandatory design rules than new building BEES. As a result, there is a remote path for China to claim the energy-saving and emission reduction potential in building energy retrofitting. A more specific, integrated policy with engineering, economic and social considerations should be well-developed.

\section{6) Rural buildings}

Similar as building retrofitting, the problems of ECPB implementation in rural buildings are also in a critical stage, and even more serious and complicated. Policies reviewed show that since majority of rural buildings are usually constructed and operating without any consideration of BEES before 2013 
when the first rural BEES released [79], the amount of energy-saving potential could be numerous. With the development of rural economy in recent years [49], the trend is that people start to seek a better indoor thermal comfort in rural area. Therefore, the country should present a comprehensive ECPB approach for the new and existing rural buildings. Yet the challenges are also tough - there are more unique considerations for rural buildings.

\section{Conclusions}

This study used chronological review method to review, retrospect and analyse the historical development, policy content, and policy effectiveness of China's Eneryg Conservation Policy of Buildings (ECPB). The clear grand picture and detailed development stages are acquired; the milestone policy and achievements of ECPB historical development are discussed and evidenced; and their policy barriers and suggestions are discovered. The major conclusions can be summarized as follows.

Firstly, massive policy content reviewed in this chronological review study can novelty provide extremely informative and coherent data for relevant studies of building energy in China. The grand picture of ECPB historical development is acquired with four detailed stages identified and categrised, and identification of the milestones during the ECPB development have showed their historical importance to launch new stages of ECPB development. Since the policy upgrades prove that the ECPB system has significantly different and improved stages and transitions during the timeline development, it is also evidenced that future ECPB designs should be closely connected to the timely demand of national objectives of energy, building and environment.

Secondly, the structure and positive effects of top-down administrative policy measures are evidenced from the disscsuion. It is found that GPEBE system is constructed by components of the Five-Year Plan, National Notice, Laws to set national objectives in energy, environment and economy aspects. These objectives are followed and achieved by detailed BEES system underpinned by individual standards for different climatic zones and building types. Accordingly, this thorough system is the key to effectively implement relevant regulations to construction sites in China. Consequently, magnificent achievements have been obtained in building energy conservation and carbon emissions reduction.

More importantly, exsiting policy barriers and problems which are uniquely identified in this paper should draw policymakers' attentions based on the evidence discussed. Consequent suggestions are proposed and solutions are disscsued for a better future of China's ECPB development. Exposed issues discovered in this study could become guidance to support policymakers for their future ECPB designs. By overcoming current policy barriers, the next stage of ECPB development in the future can be inferred as the insight of this research - the fifth stage of 'entire improvementt' after the current "further enhancement stage" in the China future ECPB development. Combined with the review and disscsuion, it is suggested that national GPEBE such as the next $14^{\text {th }}$ Five-Year Plans to have more detailed objectives in renewable energy, sustainability, building retrofit, and rural buildings. For future BEES, balanced frequency of content updates with better, stricter and more appropriate local design parameters are adviced, with stronger supervison authority applied to building engineering site to achieve higher implementation rate and better result of energy conservation.

Finally, this study also novelty demonstrate a systemic approach of policy review in an extremely long 
timeline and country-scale. Extensively, this method can be applicable to other countries to evaluate their policy of building energy conservation, and discover their own historical development, achievements and problems.

\section{Acknowledgement}

This research is supported by UK-China collaborative research project 'Low carbon climate-responsive Heating and Cooling of Cities (LoHCool)' sponsored jointly by the UK Engineering and Physical Sciences Research Council [EPSRC Grant No. EP/N009797/1] and the National Natural Science Foundation of China [NSFC Grant No. 51561135002]. The project is associated with the National Key R\&D Program, China SSHCool Project 'Solutions to Heating and Cooling of Buildings in the Yangtze River Region' [Grant No. 2016YFC0700300]. The author would like to sincerely acknowledge Professor Stuart Green of the University of Reading, for his massive professional comments, extremely helpful academic support and limitless patience for this research. 


\section{Reference}

[1] National Development and Reform Commission of China, "The people's republic of China national report on sustainable development," ed. Beijing, 2011.

[2] Ministry of Housing and Urban-Rural Development of the People's Republic of China, "GB 50189-2015, Design standard for energy efficiency of public buildings," ed. Beijing: MOHURD, 2015.

[3] United Nations Development Programme. China National Human Development Report 2013 [Online]. Available: http://www.hdr.undp.org/sites/default/files/china nhdr 2013 en final.pdf

[4] R. Yao, V. Costanzo, X. Li, Q. Zhang, and B. Li, "The effect of passive measures on thermal comfort and energy conservation. A case study of the hot summer and cold winter climate in the Yangtze River region," Journal of Building Engineering, vol. 15, pp. 298-310, 2018.

[5] M. Hill and F. Varone, The public policy process. Routledge, 2014.

[6] M. Stenmark, Environmental ethics and policy-making. Routledge, 2017.

[7] H.-L. Kangas, D. Lazarevic, and P. Kivimaa, "Technical skills, disinterest and non-functional regulation: Barriers to building energy efficiency in Finland viewed by energy service companies," Energy Policy, vol. 114, pp. 63-76, 2018.

[8] T. Lee and R. Yao, "Incorporating technology buying behaviour into UK-based long term domestic stock energy models to provide improved policy analysis," Energy Policy, vol. 52, pp. 363-372, 2013.

[9] P. Wu, Y. Song, W. Shou, H. Chi, H.-Y. Chong, and M. Sutrisna, "A comprehensive analysis of the credits obtained by LEED 2009 certified green buildings," Renewable and Sustainable Energy Reviews, vol. 68, pp. 370-379, 2017.

[10] United Nations Climate Change. (2018). The Paris Agreement. Available: https://unfccc.int/processand-meetings/the-paris-agreement/the-paris-agreement

[11] Building energy conservation research center. China Building Energy Use 2017 [Online]. Available: https://berc.bestchina.org/?ky/Article250/88.html

[12] S. Hu, D. Yan, Y. Cui, and S. Guo, "Urban residential heating in hot summer and cold winter zones of China-Status, modeling, and scenarios to 2030," Energy Policy, vol. 92, pp. 158-170, 2016.

[13] F. H. Doppen, "Incorporating archives in social studies methods," 2009.

[14] L. Cai, S. Qu, and G. Cheng, "Two-archive method for aggregation-based many-objective optimization," Information Sciences, vol. 422, pp. 305-317, 2018.

[15] M. C. Whitlock et al., "A Balanced Data Archiving Policy for Long-Term Studies," Trends Ecol Evol, vol. 31, no. 2, pp. 84-85, Feb 2016.

[16] W. Pan, "System boundaries of zero carbon buildings," Renewable and Sustainable Energy Reviews, vol. 37, pp. 424-434, 2014. 
[17] W. Pan, K. Li, and Y. Teng, "Rethinking system boundaries of the life cycle carbon emissions of buildings," Renewable and Sustainable Energy Reviews, vol. 90, pp. 379-390, 2018.

[18] J. Li and B. Shui, "A comprehensive analysis of building energy efficiency policies in China: status quo and development perspective," Journal of Cleaner Production, vol. 90, pp. 326-344, 2015.

[19] T. Hong, "A close look at the China Design Standard for Energy Efficiency of Public Buildings," Energy and Buildings, vol. 41, no. 4, pp. 426-435, 2009.

[20] D. Yan, T. Hong, C. Li, Q. Zhang, J. An, and S. Hu, "A thorough assessment of China's standard for energy consumption of buildings," Energy and Buildings, vol. 143, pp. 114-128, 2017.

[21] Y. Li, X. Chen, X. Wang, Y. Xu, and P.-H. Chen, "A review of studies on green building assessment methods by comparative analysis," Energy and Buildings, vol. 146, pp. 152-159, 2017.

[22] Y. Yang, B. Li, and R. Yao, "A method of identifying and weighting indicators of energy efficiency assessment in Chinese residential buildings," Energy Policy, vol. 38, no. 12, pp. 7687-7697, 2010.

[23] Y. Zhang, J. Wang, F. Hu, and Y. Wang, "Comparison of evaluation standards for green building in China, Britain, United States," Renewable and Sustainable Energy Reviews, vol. 68, pp. 262-271, 2017.

[24] H. Peng and Y. Liu, "A comprehensive analysis of cleaner production policies in China," Journal of Cleaner Production, vol. 135, pp. 1138-1149, 2016.

[25] W. Jiao and F. Boons, "Policy durability of Circular Economy in China: A process analysis of policy translation," Resources, Conservation and Recycling, vol. 117, pp. 12-24, 2017.

[26] X.-g. Zhao, T.-t. Feng, L. Cai, and X. Feng, "The barriers and institutional arrangements of the implementation of renewable portfolio standard: A perspective of China," Renewable and Sustainable Energy Reviews, vol. 30, pp. 371-380, 2014.

[27] M. Economidou, V. Todeschi, P. Bertoldi, D. D. Agostino, L. J. E. Castellazzi, and Buildings, "Review of 50 years of EU Energy Efficiency Policies for Buildings," p. 110322, 2020.

[28] Ministry of Housing and Urban-Rural Development of the People's Republic of China, "GB 50189-2005, Design standard for energy efficiency of public buildings," ed. Beijing: MOHURD, 2005.

[29] U. H. Graneheim, B. M. Lindgren, and B. Lundman, "Methodological challenges in qualitative content analysis: A discussion paper," Nurse Educ Today, vol. 56, pp. 29-34, Sep 2017.

[30] T. Huo et al., "China's energy consumption in the building sector: A Statistical Yearbook-Energy Balance Sheet based splitting method," Journal of Cleaner Production, vol. 185, pp. 665-679, 2018.

[31] M. Zhang, M. Wang, W. Jin, and C. Xia-Bauer, "Managing energy efficiency of buildings in China: A survey of energy performance contracting (EPC) in building sector," Energy Policy, vol. 114, pp. 13-21, 2018.

[32] X. Liu, H. Ren, Y. Wu, and D. Kong, "An analysis of the demonstration projects for renewable energy application buildings in China," Energy Policy, vol. 63, pp. 382-397, 2013.

[33] X. Yuan, X. Wang, and J. Zuo, "Renewable energy in buildings in China-A review," Renewable and Sustainable Energy Reviews, vol. 24, pp. 1-8, 2013.

[34] R. Yao, B. Li, and K. Steemers, "Energy policy and standard for built environment in China," Renewable Energy, vol. 30, no. 13, pp. 1973-1988, 2005. 
[35] X. Kong, S. Lu, and Y. Wu, "A review of building energy efficiency in China during "Eleventh Five-Year Plan" period," Energy Policy, vol. 41, pp. 624-635, 2012.

[36] D. Li, J. He, and L. Li, "A review of renewable energy applications in buildings in the hot-summer and warm-winter region of China," Renewable and Sustainable Energy Reviews, vol. 57, pp. 327-336, 2016.

[37] Y. Zhang and Y. Wang, "Barriers' and policies' analysis of China's building energy efficiency," Energy Policy, vol. 62, pp. 768-773, 2013.

[38] W. G. Cai, Y. Wu, Y. Zhong, and H. Ren, "China building energy consumption: Situation, challenges and corresponding measures," Energy Policy, vol. 37, no. 6, pp. 2054-2059, 2009.

[39] X. Yuan and J. Zuo, "Transition to low carbon energy policies in China-from the Five-Year Plan perspective," Energy Policy, vol. 39, no. 6, pp. 3855-3859, 2011.

[40] R.-D. Chang et al., "Sustainability attitude and performance of construction enterprises: A China study," Journal of Cleaner Production, vol. 172, pp. 1440-1451, 2018.

[41] B. Huang, V. Mauerhofer, and Y. Geng, "Analysis of existing building energy saving policies in Japan and China," Journal of Cleaner Production, vol. 112, pp. 1510-1518, 2016.

[42] Q. Chai and X. Zhang, "Technologies and policies for the transition to a sustainable energy system in china," Energy, vol. 35, no. 10, pp. 3995-4002, 2010.

[43] X. Tan, H. Lai, B. Gu, Y. Zeng, and H. Li, "Carbon emission and abatement potential outlook in China's building sector through 2050," Energy Policy, vol. 118, pp. 429-439, 2018.

[44] S. Zheng, C.-M. Lam, S.-C. Hsu, and J. Ren, "Evaluating efficiency of energy conservation measures in energy service companies in China," Energy Policy, vol. 122, pp. 580-591, 2018.

[45] L. Zhou, J. Li, and Y. H. Chiang, "Promoting energy efficient building in China through clean development mechanism," Energy Policy, vol. 57, pp. 338-346, 2013.

[46] J. Li, "Energy performance heterogeneity in China's buildings sector: A data-driven investigation," Renewable and Sustainable Energy Reviews, vol. 58, pp. 1587-1600, 2016.

[47] T. Huo, H. Ren, and W. Cai, "Estimating urban residential building-related energy consumption and energy intensity in China based on improved building stock turnover model," Sci Total Environ, vol. 650, no. Pt 1, pp. 427-437, Feb 102019.

[48] Q. Guo, Y. Wu, Y. Ding, W. Feng, and N. Zhu, "Measures to enforce mandatory civil building energy efficiency codes in China," Journal of Cleaner Production, vol. 119, pp. 152-166, 2016.

[49] China Association of Building Energy Efficiency. Research Report of China Building Energy Consumption 2016 [Online]. Available: http://www.efchina.org/Attachments/Report/report-201707101/report-20170710-1

[50] T. Hong, C. Li, and D. Yan, "Updates to the China Design Standard for Energy Efficiency in public buildings," Energy Policy, vol. 87, pp. 187-198, 2015.

[51] S. Yu, J. Eom, M. Evans, and L. Clarke, "A long-term, integrated impact assessment of alternative building energy code scenarios in China," Energy Policy, vol. 67, pp. 626-639, 2014.

[52] Y. Zhang, C.-Q. He, B.-J. Tang, and Y.-M. Wei, "China's energy consumption in the building sector: A life cycle approach," Energy and Buildings, vol. 94, pp. 240-251, 2015. 
[53] B. Li, C. Du, R. Yao, W. Yu, and V. Costanzo, "Indoor thermal environments in Chinese residential buildings responding to the diversity of climates," Applied Thermal Engineering, vol. 129, pp. 693-708, 2018.

[54] B. Li, R. Yao, Q. Wang, and Y. Pan, "An introduction to the Chinese Evaluation Standard for the indoor thermal environment," Energy and Buildings, vol. 82, pp. 27-36, 2014.

[55] Z. Wei et al., "A study of city-level building energy efficiency benchmarking system for China," Energy and Buildings, vol. 179, pp. 1-14, 2018.

[56] J. Hou, Y. Liu, Y. Wu, N. Zhou, and W. Feng, "Comparative study of commercial building energyefficiency retrofit policies in four pilot cities in China," Energy Policy, vol. 88, pp. 204-215, 2016.

[57] F. Guo, L. Kurdgelashvili, M. Bengtsson, and L. Akenji, "Analysis of achievable residential energysaving potential and its implications for effective policy interventions: A study of Xiamen city in southern China," Renewable and Sustainable Energy Reviews, vol. 62, pp. 507-520, 2016.

[58] National Development and Reform Commission. The 8th Five Year Plan for National Economic and Social Development in People's Republic of China (outline) [Online]. Available: http://www.ndrc.gov.cn/fzgggz/fzgh/ghwb/gijh/200506/W020050715581806145575.pdf

[59] National Development and Reform Commission. The 7th Five Year Plan for National Economic and Social Development in People's Republic of China (outline) [Online]. Available: http://www.ndrc.gov.cn/fzgggz/fzgh/ghwb/gijh/200506/W020050715581805921895.pdf

[60] National Development and Reform Commission. The 9th Five Year Plan for National Economic and Social Development in People's Republic of China (outline) [Online]. Available: http://www.ndrc.gov.cn/fzgggz/fzgh/ghwb/gjih/200506/W020050614801665203975.pdf

[61] Reports of CPC News. Review of historical problems in 9th Five-Year Plans in history [Online]. Available: http://dangshi.people.com.cn/GB/151935/204121/205066/12926029.html

[62] Reports of CPC News, "Review of all Five-Year Plans in history, 2016," ed: CPC News, 2016.

[63] National Development and Reform Commission. The 11th Five Year Plan for National Economic and Social Development in People's Republic of China (outline) [Online]. Available: http://ghs.ndrc.gov.cn/zttp/ghid/quanwen/

[64] R. J. Heffron and K. Talus, "The evolution of energy law and energy jurisprudence: Insights for energy analysts and researchers," Energy Research \& Social Science, vol. 19, pp. 1-10, 2016.

[65] J. Liu, "China's renewable energy law and policy: A critical review," Renewable and Sustainable Energy Reviews, vol. 99, pp. 212-219, 2019.

[66] P. Pearson, and Jim Watson, "UK Energy Policy 1980-2010: A History and Lessons to be Learnt," 2012.

[67] The National People's Congress. Energy Conservation Law [Online]. Available: http://www.nea.gov.cn/2017-11/03/c 136725225.htm

[68] J. Rosenow and N. Eyre, "A post mortem of the Green Deal: Austerity, energy efficiency, and failure in British energy policy," Energy Research \& Social Science, vol. 21, pp. 141-144, 2016.

[69] The National People's Congress. Circular Economy Promotion Law [Online]. Available: http://www.gov.cn/flfg/2008-08/29/content 1084355.htm 
[70] The National People's Congress. Environmental Impact Assessment Law [Online]. Available: http://www.nea.gov.cn/2017-11/02/c 136722887.htm

[71] The National People's Congress. Environmental Protection Tax Law [Online]. Available: http://www.mee.gov.cn/gzfw 13107/zcfg/fl/201704/t20170417 411610.shtml

[72] The National People's Congress. Environmental Protection Law [Online]. Available: http://www.nea.gov.cn/2017-11/02/c 136722862.htm

[73] China Academy of Building Research, "GB 50189-93, Energy conservation design standard on building envelope and air conditioning for tourist hotels," ed. Beijing: CABR, 1994.

[74] Ministry of Housing and Urban-Rural Development of the People's Republic of China, "JGJ 26-95, Energy conservation design standard for new heating residential buildings," ed. Beijing: MOHURD, 1996.

[75] Ministry of Housing and Urban-Rural Development of the People's Republic of China, "JGJ 134-2010, Design standard for energy efficiency of residential buildings in hot summer and cold winter zone," ed. Beijing: MOHURD, 2010.

[76] Ministry of Housing and Urban-Rural Development of the People's Republic of China, "JGJ 75-2012, Design standard for energy efficiency of residential buildings in hot summer and warm winter zone," ed. Beijing: MOHURD, 2013.

[77] Ministry of Housing and Urban-Rural Development of the People's Republic of China, "GB 50736-2012, Design code for heating ventilation and air conditioning of civil buildings," ed. Beijing: MOHURD, 2012.

[78] Ministry of Housing and Urban-Rural Development of the People's Republic of China, "JGJ 176-2009, Technical code for the retrofitting of public building on energy efficiency ", ed. Beijing: MOHURD, 2009.

[79] Ministry of Housing and Urban-Rural Development of the People's Republic of China, "GB/T 508242013, Design standard for energy efficiency of rural residential buildings," ed. Beijing: MOHURD, 2013.

[80] Ministry of Housing and Urban-Rural Development of the People's Republic of China, "GB/T 503782014, Assessment standard for green building," ed. Beijing: MOHURD, 2015.

[81] Ministry of Housing and Urban-Rural Development of the People's Republic of China, "GB/T 503782019, Assessment standard for green building," ed. Beijing: MOHURD, 2019.

[82] Ministry of Housing and Urban-Rural Development of the People's Republic of China, "GB/T 506682011, Standard for energy efficient building assessment," ed. Beijing: MOHURD, 2012.

[83] Ministry of Housing and Urban-Rural Development of the People's Republic of China, "Technical Guidelines of Passive, Ultra-low energy consumption, and Green buildings," ed. Beijing: MOHURD, 2015.

[84] Ministry of Housing and Urban-Rural Development of the People's Republic of China, "GB/T 513502019, Technical Standard for Nearly-Zero Energy building," ed. Beijing: MOHURD, 2019.

[85] Ministry of Housing and Urban-Rural Development of the People's Republic of China, "JGJ/T 229-2010, Code for green design of civil buildings," ed. Beijing: MOHURD, 2011.

[86] National Development and Reform Commission. The Detail Plan of Energy Development in 11th Five Year Plan [Online]. Available: http://zfxxgk.nea.gov.cn/auto79/201109/P020110921527315023013.pdf 
[87] S. Chen, H. Yoshino, and N. Li, "Statistical analyses on summer energy consumption characteristics of residential buildings in some cities of China," Energy and Buildings, vol. 42, no. 1, pp. 136-146, 2010.

[88] M. Potůček, Public Policy: A Comprehensive Introduction. Charles University in Prague, Karolinum Press, 2018.

[89] Eurostat newsrelease. Share of renewables in energy consumption in the EU reached 17\% in 2016 [Online]. Available: https://ec.europa.eu/eurostat/documents/2995521/8612324/8-25012018-APEN.pdf/9d28caef-1961-4dd1-a901-af18f121fb2d

[90] European Commission. Renewable energy directive [Online]. Available: https://ec.europa.eu/energy/en/topics/renewable-energy/renewable-energy-directive

[91] Gabrielle Garton and Elena Ares. Energy: The Renewables Obligation [Online]. Available: https://www.parliament.uk/commons-library

[92] The National People's Congress. Cleaner Production Promotion Law [Online]. Available: http://www.mee.gov.cn/gzfw 13107/zcfg/fl/201605/t20160522 343374.shtml

[93] The National People's Congress. Renewable Energy Law [Online]. Available: http://www.npc.gov.cn/wxzl/wxzl/2005-04/25/content 337639.htm 


\section{Appendix A}

Review of the $7^{\text {th }}-13^{\text {th }}$ Five-Year Plans

Summary of the policy objective information from the Five-Year Plans in development of energy, building and environment

\begin{tabular}{|c|c|c|c|c|}
\hline FYP & Year & Energy & Building & Environment \\
\hline $7^{\text {th }}$ & $\begin{array}{l}1986- \\
1990\end{array}$ & $\begin{aligned}> & 3.4 \% \text { annual increased of } \\
& \text { energy generation } \\
> & 17.6 \% \text { increased coal } \\
& \text { production, } 20 \% \text { oil, } 16.6 \% \\
& \text { natural gas } \\
> & \text { Reduce oil-burning to } 18 \% \\
& \text { from } 40 \% \\
> & 23.5 \% \text { total investment for } \\
& \text { energy facilities } \\
> & 11.6 \% \text { energy conservation rate } \\
> & \text { Reduce energy consumption } \\
& \text { as } 100 \text { million tons of SCE }\end{aligned}$ & $\begin{aligned}> & 40 \% \text { increased output value } \\
> & \text { Spread usage of standard glazing } \\
> & \text { Develop higher energy-efficient } \\
& \text { wood/coal boilers } \\
> & 650 \text { million } \mathrm{m}^{2} \text { more urban } \\
& \text { residential buildings } \\
> & 50 \text { million } \mathrm{m}^{2} \text { more central heating } \\
& \text { area }\end{aligned}$ & $\begin{array}{l}\text { Encourage biogas and } \\
\text { hydropower facilities in rural area }\end{array}$ \\
\hline $8^{\text {th }}$ & $\begin{array}{l}1991- \\
1995\end{array}$ & $\begin{aligned}> & 32 \% \text { increased electricity } \\
& \text { generation } \\
> & 12.8 \text { increased coal production, } \\
& 5 \% \text { oil } \\
> & \text { Reduce energy consumption } \\
& \text { as } 100 \text { million tons of SCE } \\
> & 2.2 \% \text { annual energy saving } \\
& \text { rate for five years }\end{aligned}$ & $\begin{array}{l}\text { Improve and retrofit urban plan and } \\
\text { basic facilities } \\
\text { More construction projects of public } \\
\text { buildings }\end{array}$ & $\begin{array}{l}\text { Develop facilities of waste and } \\
\text { pollution treatment }\end{array}$ \\
\hline $9^{\text {th }}$ & $\begin{array}{l}1996- \\
2000\end{array}$ & $\begin{aligned} & 7 \% \text { increased electricity } \\
& \text { generation } \\
& \text { Increase the using of natural } \\
& \text { gas, further reduce oil-burning } \\
> & \text { Start to design and implement } \\
& \text { energy conservation } \\
& \text { regulations }\end{aligned}$ & $\begin{aligned} &> 500 \text { billion CNY increased output } \\
& \text { value } \\
&> 1 \text { billion } \mathrm{m}^{2} \text { more urban residential } \\
& \text { buildings } \\
&>\text { Start to limit poor thermal } \\
& \text { performance brick buildings } \\
&>\text { Start to retrofit poor thermal } \\
& \text { designed old buildings }\end{aligned}$ & $\begin{array}{l}\text { Encourage using of all kinds of } \\
\text { renewable energy sources } \\
>\quad \text { Increased industrial water waste } \\
\text { treatment rate to } 83 \% \text {, gas waste } \\
86 \% \\
>\quad 50 \% \text { Recycle rate of solid waste } \\
>\quad 27 \% \text { urban water waste } \\
\text { treatment rate, domestic } \\
\text { garbage } 50 \%\end{array}$ \\
\hline $10^{\text {th }}$ & $\begin{array}{l}2001- \\
2005\end{array}$ & $\begin{array}{l}\text { Optimize the structure of } \\
\text { energy generation and } \\
\text { consumption } \\
\text { Improve the efficiency of } \\
\text { exploitation and utilisation coal, } \\
\text { oil and gas mines and products } \\
\text { Further increase the usage and } \\
\text { generation of primary electricity } \\
\text { instead of fossil fuel burning }\end{array}$ & $\begin{aligned}> & \text { Optimize the economy structure of } \\
& \text { urban and rural area } \\
> & \text { Increased urbanisation rate } \\
> & \text { Increased development of urban } \\
& \text { public buildings and facilities } \\
> & \text { Average residential area per } \\
& \text { person increased to } 22 \mathrm{~m}^{2}\end{aligned}$ & $\begin{array}{l}>\text { Environment and sustainability } \\
\text { became one major section in the } \\
\text { plan } \\
>10 \% \text { reduced overall pollution } \\
>\text { Issue water, grassland, ocean } \\
\text { and forest protection policies } \\
>45 \% \text { urban water waste } \\
\text { treatment rate, up from } 27 \% \\
>20 \% \text { reduced sulfur dioxide } \\
\text { emission } \\
>\text { Forest cover rate to } 18.2 \%\end{array}$ \\
\hline $11^{\text {th }}$ & $\begin{array}{l}2006- \\
2010\end{array}$ & $\begin{aligned} & 9.82 \% \text { increased annual } \\
& \text { primary energy generation } \\
> & 4 \% \text { increased annual energy } \\
& \text { consumption } \\
> & \text { Reduce energy consumption } \\
& \text { as } 560 \text { million tons of SCE } \\
> & 4.4 \% \text { annual energy } \\
& \text { conservation rate }\end{aligned}$ & $\begin{aligned} & 150 \text { million } \mathrm{m}^{2} \text { houses get energy } \\
& \text { efficient retrofit } \\
> & \text { Increase all energy efficiency rate } \\
& \text { of facilities and equipment in } \\
& \text { buildings } \\
> & \text { Increase central heating supply rate } \\
& \text { to } 40 \% \text { from } 30 \% \\
> & \text { Develop new materials for better }\end{aligned}$ & $\begin{array}{l}>10 \% \text { reduced overall pollution } \\
>320 \text { million tons of reduced } \\
\text { carbon dioxide emission } \\
>\quad 8.4 \text { million tons reduced sulfur } \\
\text { dioxide emission } \\
>\text { Reduce the number of coal } \\
\text { mines } \\
>5000 \mathrm{~m}^{2} \text { solar-heating hot water }\end{array}$ \\
\hline
\end{tabular}




\begin{tabular}{|c|c|c|c|c|}
\hline FYP & Year & Energy & Building & Environment \\
\hline & & $\begin{array}{l}1.8 \%, 0.1 \%, 0.8 \%, 0.4 \% \\
\text { increased usage of natural gas, } \\
\text { nuclear, hydraulic and other } \\
\text { renewable energy }\end{array}$ & $\begin{array}{l}\text { thermal and energy efficiency } \\
\text { building design }\end{array}$ & $\begin{array}{l}\text { facilities } \\
156 \text { billion CNY appropriation for } \\
\text { environmental protection }(200 \% \\
\left.\text { more than } 10^{\text {th }} \mathrm{FYP}\right)\end{array}$ \\
\hline $12^{\text {th }}$ & $\begin{array}{l}2011- \\
2015\end{array}$ & $\begin{aligned} & \text { 'Energy' section was converted } \\
& \text { as 'Energy and sustainability' } \\
& \text { section } \\
&>\quad \text { Energy generation and } \\
& \text { consumption increase rate are } \\
& \text { no longer objectives } \\
&>11.4 \% \text { non-fossil fuel resources } \\
& \text { usage } \\
&>16 \% \text { energy conservation rate } \\
& \text { in five years } \\
&>\text { Issue energy-label system and } \\
& \text { consummate the energy } \\
& \text { conservation regulations } \\
&>\quad 4 \% \text { replacement rate of } \\
& \text { renewable energy to total } \\
& \text { energy }\end{aligned}$ & $\begin{aligned} & 990 \text { million } \mathrm{m}^{2} \text { houses get energy } \\
& \text { efficient retrofit } \\
&> 100 \% \text { rate of building standards } \\
& \text { apply to urban new buildings } \\
&> 36 \text { million more sets of affordable } \\
& \text { urban housing } \\
&> \text { Issue new building design } \\
& \text { standards and codes } \\
&> \text { Develop public building and } \\
& \text { facilities in rural area } \\
&> \text { Strongly encourage the new energy } \\
& \text { saving techniques in building } \\
& \text { design } \\
&> \text { Massive appropriation in building } \\
& \text { and HVAC energy-efficient } \\
& \text { research } \\
&> \text { Stably increase the urbanisation }\end{aligned}$ & $\begin{array}{l}\text { 17\% reduced carbon dioxide } \\
\text { emission } \\
\text { 8\% reduced sulfur dioxide } \\
\text { emission and chemical oxygen } \\
\text { demand } \\
>10 \% \text { reduced ammonia oxide } \\
\text { and nitrogen oxide emission } \\
>\text { Forest cover rate to } 21.66 \% \\
>\text { Control and solve the urban air- } \\
\text { pollution issues } \\
>\quad 85 \% \text { urban water waste } \\
\text { treatment rate, domestic } \\
\text { garbage } 80 \% \\
>\text { Strengthen the environmental } \\
\text { supervision and management }\end{array}$ \\
\hline $13^{\text {th }}$ & $\begin{array}{l}2016- \\
2020\end{array}$ & $\begin{aligned}> & 15 \% \text { non-fossil fuel resources } \\
& \text { usage } \\
> & 15 \% \text { energy conservation rate } \\
& \text { in five years } \\
> & \text { Limit coal mine development } \\
> & \text { Develop primary electricity and } \\
& \text { renewable energy } \\
> & \text { Coal consumption share } \\
& \text { reduced to } 62 \% \\
> & 6 \% \text { replacement rate of } \\
& \text { renewable energy to total } \\
& \text { energy }\end{aligned}$ & $\begin{aligned} & 500 \mathrm{~m}^{2} \text { residential and } 100 \text { million } \\
& \mathrm{m}^{2} \text { public buildings get energy } \\
& \text { efficient retrofit each year } \\
&> 50 \% \text { increased green buildings in } \\
& \text { urban new buildings } \\
&> \text { Accelerate and fasten the } \\
& \text { urbanisation process } \\
&> \text { Change the urban development } \\
& \text { style to improve urban } \\
& \text { environmental and living quality } \\
&> \text { Develop towns and villages } \\
&> \text { Develop and improve the public } \\
& \text { buildings and facilities in rural area } \\
&> \text { Massive appropriation in building } \\
& \text { and HVAC energy-efficient } \\
& \text { research }\end{aligned}$ & $\begin{array}{l}\text { 18\% reduced carbon dioxide } \\
\text { emission } \\
>15 \% \text { reduced sulfur dioxide and } \\
\text { nitrogen oxide emission } \\
>10 \% \text { reduced chemical oxygen } \\
\text { demand and ammonia oxide } \\
\text { emission } \\
>23 \% \text { water conservation rate } \\
>\text { Forest cover rate to } 23.04 \% \\
>\text { Control and solve the water and } \\
\text { air-pollution issues } \\
>\text { 20\% reduced land using } \\
\text { conservation rate } \\
>\text { Develop the repair projects of } \\
\text { eco-systems }\end{array}$ \\
\hline
\end{tabular}

${ }^{*}$ The conservation rate is defined as the related consumption saving per 10,000 CNY (Chinese Yuan) of GDP 


\begin{tabular}{|c|c|c|}
\hline Aggressive development & The transition & Sustainable development \\
\hline $\begin{array}{l}\text { - } \begin{array}{l}\text { Focus on developing } \\
\text { energy and construction } \\
\text { industry }\end{array} \\
\text { - No control of emission } \\
\text { and pollution } \\
\text { - No control of energy } \\
\text { efficiency } \\
\text { - No active energy and } \\
\text { environmental laws } \\
\text { No active building } \\
\text { requlation }\end{array}$ & $\begin{array}{l}\text { Reduced national } \\
\text { energy development } \\
\text { objectives } \\
\text { - } \quad \text { Heavy air and water } \\
\text { pollution problems } \\
\text { appeared } \\
\text { - } \quad \text { Start of energy } \\
\text { efficiency policy } \\
\text { - Start of energy and } \\
\text { environmental laws } \\
\text { Public and residential } \\
\text { building regulations }\end{array}$ & $\begin{array}{l}\text { - } \quad \text { Limited national energy } \\
\text { development objectives } \\
\text { - Strict emission to } \\
\text { reduce pollution } \\
\text { - Strict energy efficiency } \\
\text { and conservation policy } \\
\text { - } \quad \text { Frequent updated } \\
\text { energy and } \\
\text { environmental laws } \\
\text { Green building and } \\
\text { advanced building } \\
\text { standards issued }\end{array}$ \\
\hline
\end{tabular}

Figure Appendix A: Summary of three stages of FYPs of ECPB content 


\title{
Appendix B
}

\author{
Tables of National Notices and Actions
}

\begin{tabular}{|c|c|c|}
\hline Policy name & Year & Authority \\
\hline Notice on issue of energy conservation law & 1998 & NPC \\
\hline Notice on issue of regulation on environmental protection management of construction project & 1998 & GOV \\
\hline Notice on issue of the outline for national ecological environmental protection & 2000 & GOV \\
\hline Notice of developing abstemious society - recent key projects & 2005 & GOV \\
\hline Notice on further promoting wall material innovation and popularizing energy-saving buildings & 2005 & GOV \\
\hline Notice on further Strengthening the supervision of building energy efficiency standards & 2005 & GOV \\
\hline Notice on organizing special inspection of building energy efficiency & 2005 & GOV \\
\hline Notice on investigation work related to building energy conservation & 2005 & GOV \\
\hline Notice on decision of the State Council on strengthening energy conservation & 2006 & GOV \\
\hline Notice on issue of energy development plan in $11^{\text {th }}$ Five-Year Plan & 2007 & NDRC \\
\hline Notice on issue of the comprehensive scheme for energy-conservation and emission-reduction & 2007 & GOV \\
\hline Notice on issue of China's national plan to tackle climate change & 2007 & GOV \\
\hline Notice on issue of renewable energy development plan in $11^{\text {th }}$ Five-Year Plan & 2008 & NDRC \\
\hline Notice on issue of energy-conservation and emission-reduction plan in 2009 & 2009 & GOV \\
\hline Notice on issue of energy-conservation and emission-reduction plan in $12^{\text {th }}$ Five-Year Plan & 2012 & GOV \\
\hline Notice on issue of greenhouse gas emission reduction plan in $12^{\text {th }}$ Five-Year Plan & 2012 & GOV \\
\hline Notice of green building action plan & 2013 & MOHURD \\
\hline Notice on issue of energy development plan in $12^{\text {th }}$ Five-Year Plan & 2013 & GOV \\
\hline Notice on issue of circular economy development strategy and short-term action plan & 2013 & GOV \\
\hline Notice on issue of the energy-conservation and emission-reduction plan (2014-2015) & 2014 & GOV \\
\hline Notice on issue of the energy development strategy action plan (2014-2020) & 2014 & GOV \\
\hline Notice on issue of greenhouse gas emission reduction plan in $13^{\text {th }}$ Five-Year Plan & 2016 & GOV \\
\hline Notice on issue of energy-conservation and emission-reduction plan in $13^{\text {th }}$ Five-Year Plan & 2017 & GOV \\
\hline
\end{tabular}

\begin{tabular}{lll} 
National Actions & Year & Authority \\
\hline Policy name & 1999 & NPC \\
\hline Measures for the management of China's energy saving products certification & 1999 & NPC \\
Energy saving management method for key energy consuming units & 2000 & MOHRUD \\
Regulations for energy conservation management in civil buildings & 2004 & MOHURD \\
Guidance on developing energy-saving and land-saving housing and public buildings & 2006 & MOHURD \\
Regulations for energy conservation management in civil buildings (2 ${ }^{\text {nd }}$ edition) & 2007 & NDRC \\
Guidance on integrated utilisation of resources in 11th Five-Year Plan & 2007 & MOHURD \\
Implementation scheme of the energy-conservation and emission-reduction plan & 2008 & GOV \\
Regulation for energy conservation in civil buildings & 2008 & GOV \\
Regulation for energy conservation in public governmental buildings and facilities & 2010 & GOV \\
Opinions on accelerating the implementation of energy performance contracting (EPC) & 2013 & GOV \\
Opinions on accelerating the development of energy saving and environmental protection & 2013 & GOV \\
Guidance on strengthen the urban public facilities construction & 2013 & MOHURD \\
Green building and green eco-cities progress plan in $12^{\text {th } F i v e-Y e a r ~ P l a n ~}$ & 2015 & GOV \\
Guidance on standardisation process of energy conservation works & 2017 & MOHURD \\
Building energy conservation and green building progress plan in 13 & th Five-Year Plan & 2018 \\
Energy saving management method for key energy consuming units (2 & NPC edition) & \\
\hline
\end{tabular}




\title{
Appendix C
}

\author{
Laws of Energy and Environment in China
}

Laws of Energy and Environment

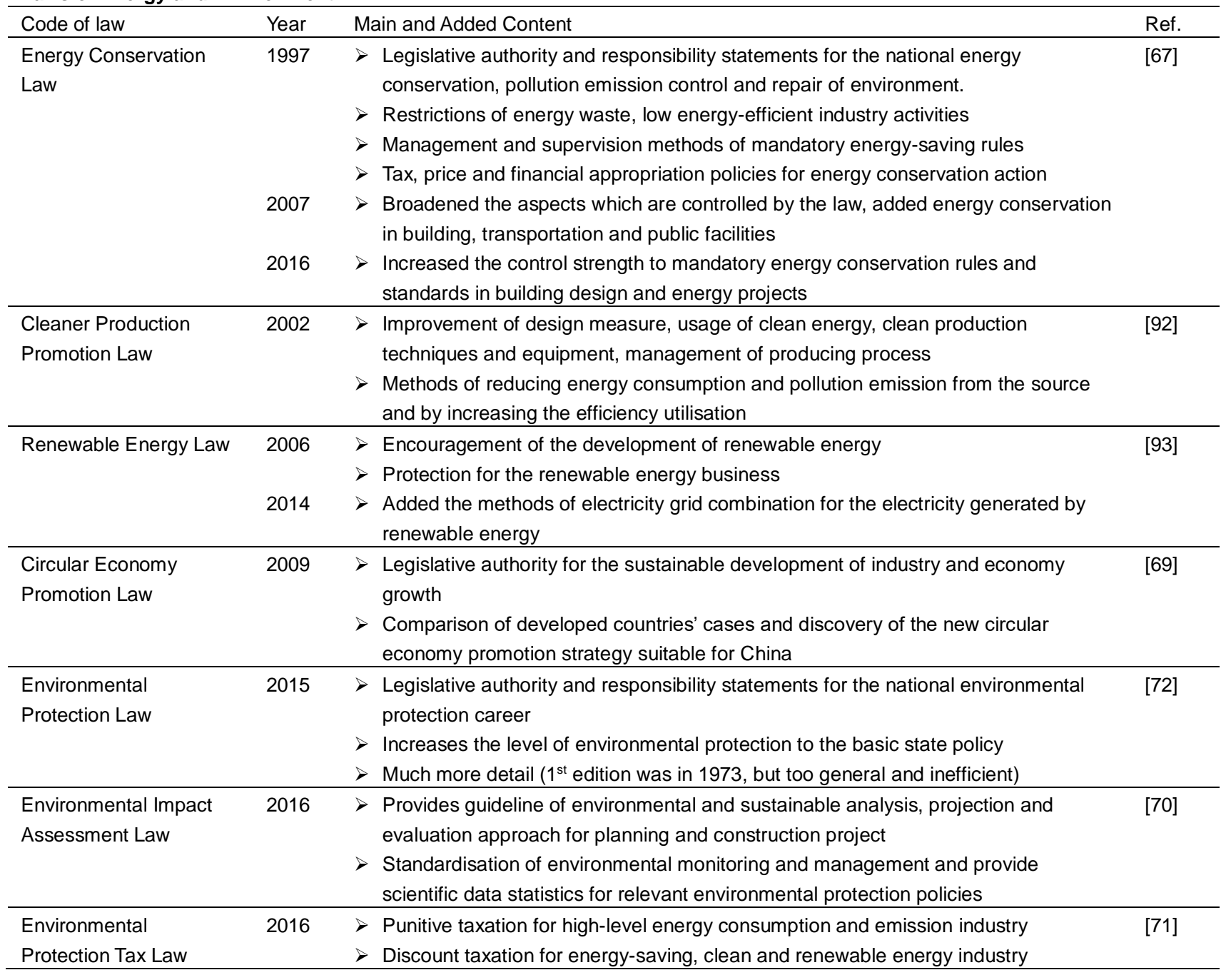




\title{
Appendix D
}

\author{
Building Energy Standards in China
}

Development of issued national building standards. Divided by the milestone BEESs (highlighted).

\begin{tabular}{|c|c|c|c|c|}
\hline Code & Standard Focus & Year & Coved Building Type & Climate Zone* $^{*}$ \\
\hline TJ 19-75 & HVAC design & 1975 & Industrial & National \\
\hline GBJ 19-87 & HVAC design & 1987 & All & National \\
\hline JGJ 26-87 & Energy conservation design for heating & 1987 & Residential & $\mathrm{SC}, \mathrm{C}$ \\
\hline JGJ 37-87 & Architectural design & 1987 & Civil & National \\
\hline GB 50176-93 & Thermal design code & 1993 & Civil & National \\
\hline GB 50189-93 & Energy conservation design & 1993 & Hotel & National \\
\hline JGJ 26-95 & Energy conservation design for heating & 1995 & Residential & SC, C \\
\hline GB 50096-1999 & Architectural design & 1999 & Residential & National \\
\hline JGJ/T 129-2000 & Energy conservation retrofitting & 2000 & Residential & National \\
\hline JGJ 134-2001 & Energy conservation design & 2001 & Residential & HSCW \\
\hline GB 50019-2003 & HVAC design & 2003 & All & National \\
\hline JGJ 75-2003 & Energy conservation design & 2003 & Residential & HSWW \\
\hline GB 50189-2005 & Energy conservation design ( $2^{\text {nd }}$ edition) & 2005 & Public & National \\
\hline GB 50352-2005 & Architectural design & 2005 & Civil & National \\
\hline GB 50368-2005 & Architectural design & 2005 & Residential & National \\
\hline GB/T 50378-2006 & Green building assessment & 2006 & Civil & National \\
\hline JGJ/T 132-2009 & Energy efficiency test & 2009 & Residential & National \\
\hline JGJ 176-2009 & Energy conservation retrofitting & 2009 & Public & National \\
\hline JGJT 177-2009 & Energy efficiency test & 2009 & Public & National \\
\hline JGJ 26-2010 & Energy conservation design & 2010 & Residential & SC, C \\
\hline JGJ 134-2010 & Energy conservation design & 2010 & Residential & HSCW \\
\hline JGJ/T 229-2010 & Green building design & 2010 & Civil & National \\
\hline GB 50096-2011 & Architectural design & 2011 & Residential & National \\
\hline GB/T 50668-2011 & Energy conservation building assessment & 2011 & Civil & National \\
\hline GB 50736-2012 & HVAC design & 2012 & Civil & National \\
\hline JGJ 75-2012 & Energy conservation design & 2012 & Residential & HSWW \\
\hline JGJ/T 129-2012 & Energy conservation retrofitting ( $2^{\text {nd }}$ edition) & 2012 & Residential & National \\
\hline GB/T 50824-2013 & Energy conservation design & 2013 & Rural residential & National \\
\hline GB/T 50378-2014 & Green building assessment ( $2^{\text {nd }}$ edition) & 2014 & Civil & National \\
\hline CSUS/GBC 05-2014 & Green building testing & 2014 & Civil & National \\
\hline GB 50189-2015 & Energy conservation design ( $3^{\text {nd }}$ edition) & 2015 & Public & National \\
\hline GB 50176-2016 & Thermal design code & 2016 & Civil & National \\
\hline GB/T 51161-2016 & Energy consumption control & 2016 & Civil & National \\
\hline
\end{tabular}

*Standards in grey color are specific building energy conservation standards

*SC for Severe Cold climate zone, C for Cold, HSCW for Hot Summer and Cold winter, HSWW for Hot Summer and Warm Winter 